Review

\title{
Enzyme (Single and Multiple) and Nanozyme Biosensors: Recent Developments and Their Novel Applications in the Water-Food-Health Nexus
}

\author{
Lynette Alvarado-Ramírez, Magdalena Rostro-Alanis, José Rodríguez-Rodríguez $\mathbb{\complement}$, Juan Eduardo Sosa-Hernández $\mathbb{C}^{\circ}$, \\ Elda M. Melchor-Martínez $\mathbb{1}$, Hafiz M. N. Iqbal $\mathbb{1}$ and Roberto Parra-Saldívar*
}

check for

updates

Citation: Alvarado-Ramírez, L.;

Rostro-Alanis, M.;

Rodríguez-Rodríguez, J.;

Sosa-Hernández, J.E.;

Melchor-Martínez, E.M.; Iqbal,

H.M.N.; Parra-Saldívar, R. Enzyme

(Single and Multiple) and Nanozyme

Biosensors: Recent Developments

and Their Novel Applications in the

Water-Food-Health Nexus. Biosensors

2021, 11, 410. https://doi.org/

10.3390/bios11110410

Received: 24 August 2021

Accepted: 22 September 2021

Published: 21 October 2021

Publisher's Note: MDPI stays neutral with regard to jurisdictional claims in published maps and institutional affiliations.

Copyright: (c) 2021 by the authors. Licensee MDPI, Basel, Switzerland. This article is an open access article distributed under the terms and conditions of the Creative Commons Attribution (CC BY) license (https:// creativecommons.org/licenses/by/ $4.0 /)$.
Tecnologico de Monterrey, School of Engineering and Sciences, Monterrey 64849, Mexico; A00814259@itesm.mx (L.A.-R.); magda.rostro@tec.mx (M.R.-A.); jrr@tec.mx (J.R.-R.); eduardo.sosa@tec.mx (J.E.S.-H.); elda.melchor@tec.mx (E.M.M.-M.); hafiz.iqbal@tec.mx (H.M.N.I.)

* Correspondence: r.parra@tec.mx; Tel.: +52-81-8358-2000

Abstract: The use of sensors in critical areas for human development such as water, food, and health has increased in recent decades. When the sensor uses biological recognition, it is known as a biosensor. Nowadays, the development of biosensors has been increased due to the need for reliable, fast, and sensitive techniques for the detection of multiple analytes. In recent years, with the advancement in nanotechnology within biocatalysis, enzyme-based biosensors have been emerging as reliable, sensitive, and selectively tools. A wide variety of enzyme biosensors has been developed by detecting multiple analytes. In this way, together with technological advances in areas such as biotechnology and materials sciences, different modalities of biosensors have been developed, such as bi-enzymatic biosensors and nanozyme biosensors. Furthermore, the use of more than one enzyme within the same detection system leads to bi-enzymatic biosensors or multi-enzyme sensors. The development and synthesis of new materials with enzyme-like properties have been growing, giving rise to nanozymes, considered a promising tool in the biosensor field due to their multiple advantages. In this review, general views and a comparison describing the advantages and disadvantages of each enzyme-based biosensor modality, their possible trends and the principal reported applications will be presented.

Keywords: biosensors; enzymes; nanozymes; laccase; glucose oxidase; horseradish peroxidase

\section{Introduction}

Biosensing is the detection signal of interaction between biological molecules with other molecules or analytes, and the device employed to sensing these interactions is a biosensor [1]. Nowadays, the rapid analysis and detection of different analytes play an essential role. Traditional chemistry analysis could represent a long time to detect because it requires extensive and expensive devices impeding the quick response. The biosensor's objective is to provide a fast and accurate response about a particular analyte with operational simplicity [2-4]. Additionally, it is possible to detect the analytes cost-effectively without the need for complicated and expensive sample preparation. Since they can be miniaturized, they could be considered for portable in situ analysis, which is critical for point-of-care diagnosis [5]. Biosensors represent a reliable alternative that can be applied to several analytical processes in numerous fields. They are successfully implemented for early disease identification, toxins, viruses, elevated blood levels, etc. [6-10]. In the food industry, biosensors are used to detect food allergens, food contamination, or antioxidant power [11-13]. In the environment, biosensors could detect pollution in the air or contaminants in water or soil [14,15].

Enzyme-based biosensors are extensively used for their high selectivity and sensitivity. For example, reduction-oxidation enzymes have been extensively used in enzyme-based 
biosensors due to their ability to catalyze reactions based on electron transfer. The most used enzymes are glucose oxidase and horseradish peroxidase. Additionally, laccase is an emerging enzyme with the capacity to oxidase a broad range of substrates without $\mathrm{H}_{2} \mathrm{O}_{2}$ in the reaction medium. Thus, electrodes could achieve the recognition of multiple analytes with two or more enzymes. However, long-term stability could be challenging due to the instability of enzymes [16]. Thus, immobilization is essential to stabilize enzymes and increase their reusability. Even when research has been focused in increased the stability of enzymes, they have limited chemical and biological stability and high cost due to their purification process. Artificial enzymes are also known as nanozymes, are nanomaterials with enzyme-like activity. They have high stability and represent an excellent choice due to their simple preparation technologies. An essential advantage of nanozymes is that to can change their catalytic activity by varying shape, structure, and composition [17]. To date, a significant number of nanozyme-based biosensors have been reported.

This review mainly focuses on the related biosensor technology, specifically in the enzyme-based biosensor and nanozyme-based biosensors. Their recent developments and variants focus on three principal enzymes: horseradish peroxidase, glucose oxidase, and laccase, as well as nanozymes with oxidase, peroxidase, and laccase-like activity. Finally, a comparison between these systems and their applications will be presented.

\section{Biosensors}

Three main parts constitute a biosensor: a recognition element or bioreceptor, that is a biomolecule that identifies the analyte; a transducer, which converts the signal (biological/chemical) into a detectable signal; and a signal reading device, which measures the transducer signal (Figure 1) $[12,18,19]$. The bioreceptor is the most crucial aspect of biosensors [20]; it is fundamentally any organic body that should detect an analyte from the medium of interest remaining other potential interfering species [1]. Different types of receptors have been reported as enzymes, microorganisms, nucleic acid fragments, antibody fragments, etc. [19]. The transducer can also be an electrochemical, optical, thermistor and piezoelectric [21]. An essential advantage in biosensors is that the bioreceptor and the transducer are integrated into one single sensor. This combination makes it possible to measure the analyte without reagents [2].

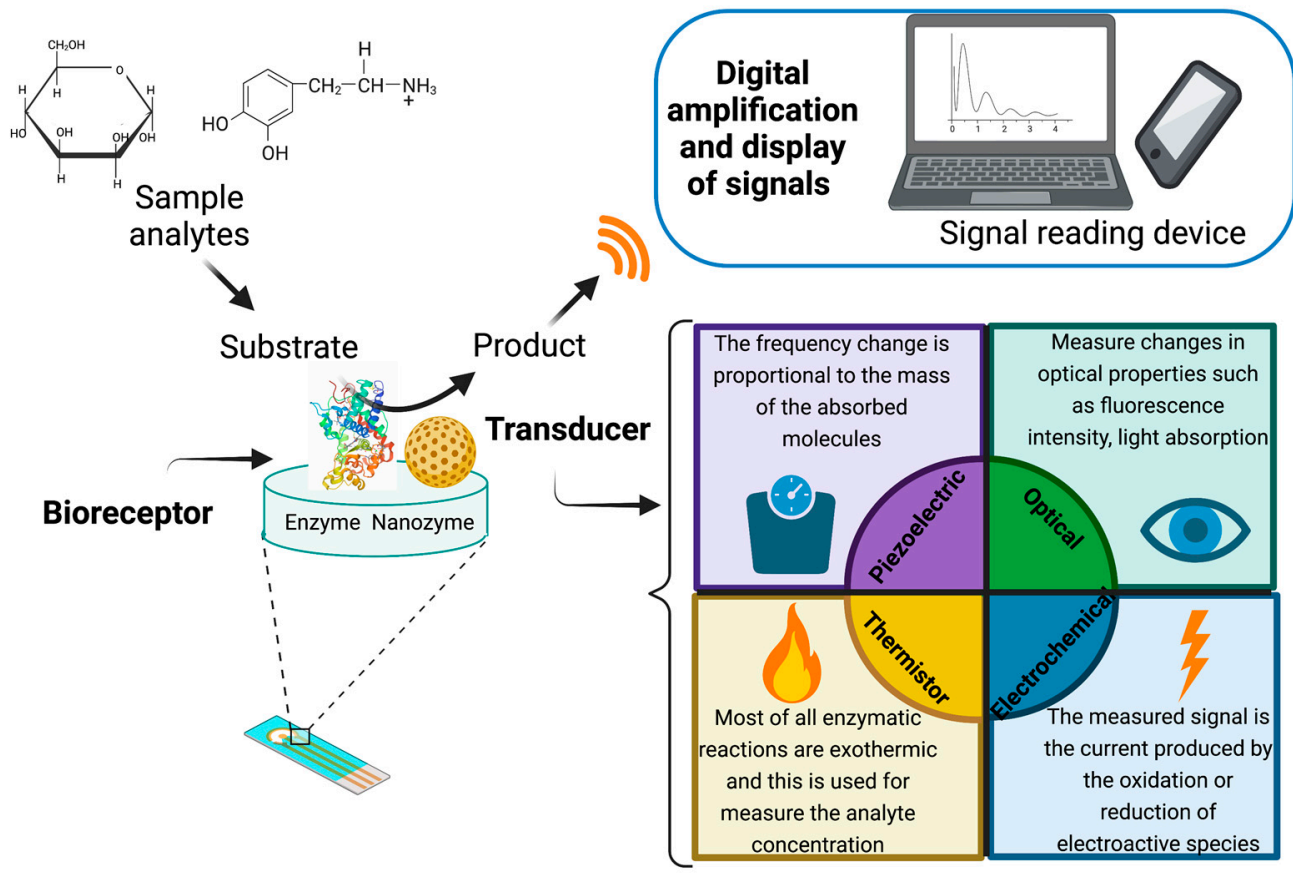

Figure 1. Main biosensing elements and their mechanistic role. 
Different approaches can be used for their classification. Commonly, biosensors can be classified on the biological component used, the type of signal transduction they employed, and the type of detected analyte [21]. The following sections will be focused on the bioreceptor, specifically, the use of enzymes and other materials with similar characteristics, focusing on the enzyme-based biosensors (single and multiple) and nanozyme biosensors.

\section{Enzyme Based Biosensors}

Enzyme-based biosensors were the earliest biosensors. In 1962, Clark proposed the idea of enzyme electrodes for a glucose sensor [22]. Subsequently, enzyme-based biosensors have been experimenting a massive growth in several applications [18]. The biological component used in enzyme-based biosensors is an enzyme. Enzymes are biological macromolecules with catalytic activity, high selectivity, and responsible for speeding up biochemical reactions under mild conditions [23]. These macromolecules can attach to one particular molecule or analyte, but not others to ensure the analyte selectivity. Due to their high specificity, simplicity, and scalability, enzyme-based biosensors represent a fast, precise, and continuous monitoring of analytes [24]. Additionally, the high specificity of enzymes enhances the ability to detect lower analyte concentration limits [18]. Additionally, the catalytic action can be influenced by the substrate concentration, temperature, $\mathrm{pH}$, and inhibitor presence [18]. The enzyme functions could be the generation of electroactive species or an electroactive reactant's consumption, causing the direct measurement of the analyte [25], or for oxidation or reduction of a molecule, which can be monitored electrochemically [26].

The crucial factor in enzyme-based biosensors is the assembly or immobilization of the enzyme on the electrode surface [16]. If the immobilization is not correctly done, the accessibility of the active site, the stability through time, and the enzyme's reusability could be affected. The enzymes can be immobilized on the transducer surface to improve the stability and reproducibility of the detection. The choice of support material is essential for conferring stability, selectivity and even improve enzyme activity. Consequently, the support material must be inert, stable, and resistant [27]. The immobilization technique is highly significant; without immobilization, the enzyme cannot be stable and reusable. The immobilized enzymes can be used continuously and can maintain their catalytic activity. Adsorption, covalent bonding, crosslinking, encapsulation and entrapment are the main methods used for immobilization [28,29]. In Figure 2 are represented the immobilization techniques with their advantages and disadvantages. The simplest methods are adsorption, encapsulation, and entrapment. Adsorption is inexpensive and straightforward; however, the enzymes have weak associations with the support [27]. Entrapment gives the enzyme high stability; however, the matrix can interfere with substrates' diffusion to the enzyme's active site. Covalent bonding is the most used method because a stable complex between the enzyme and support is generated [16]. Nevertheless, the formation of the covalent bonding could affect the enzyme activity. Crosslinking immobilization improves the stability and efficiency due to the stable binding between enzymes, generally formed with a reactant as glutaraldehyde. However, with reagents, conformational changes in the structure can affect the enzyme activity [21]. 


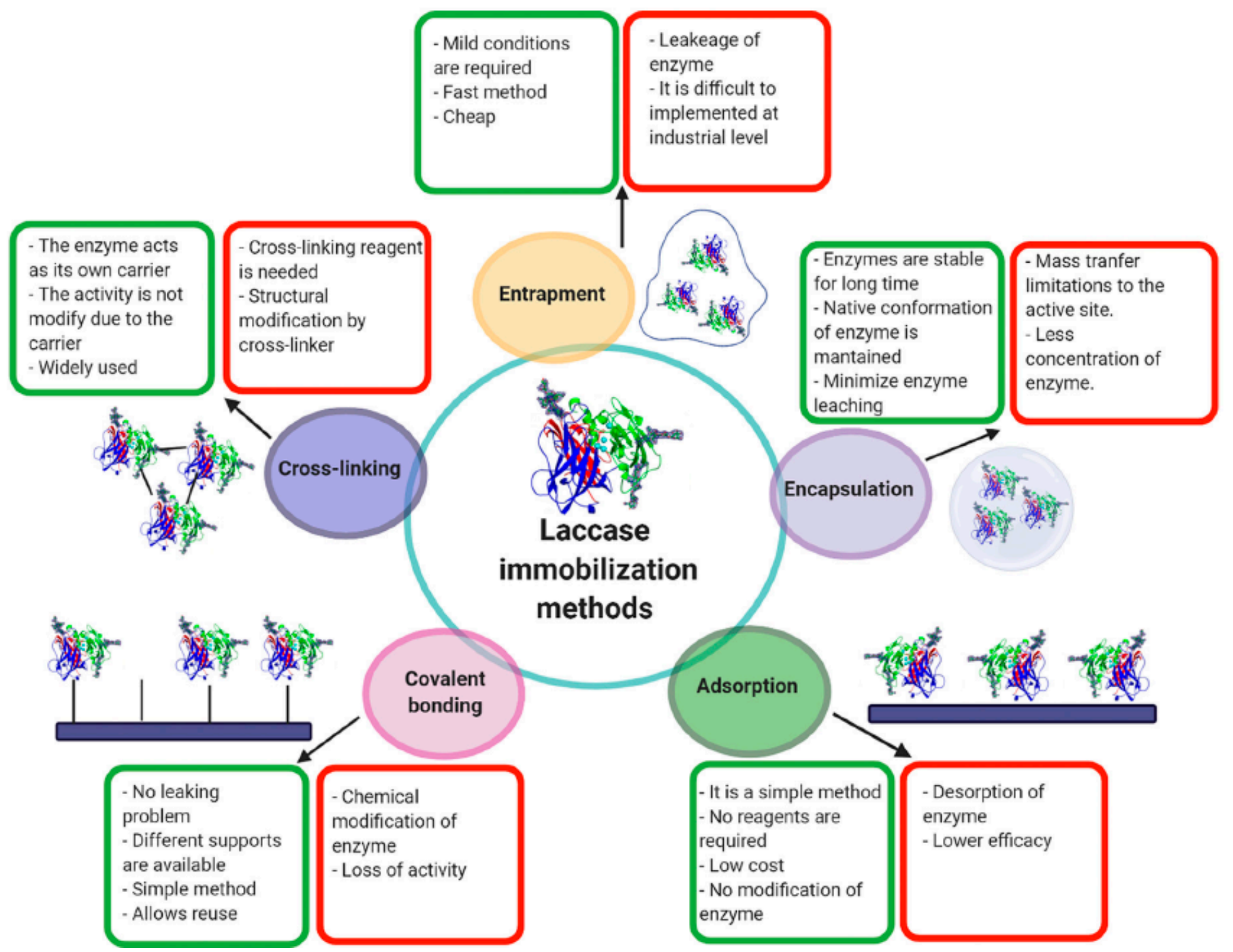

Figure 2. Schematic illustration of five basic immobilization techniques along with their advantages (green) and disadvantages (red). Reprinted from Ref. [29] with permission from Elsevier. License Number: 5151170420861.

Even though the advantages of using enzymes, some disadvantages, such as the rapid loss of enzyme activity due to its interactions with the electrode surface, cause a biosensor's lifespan is only 2-4 weeks. However, if the enzyme is well stabilized, this can increase [30]. Therefore, choosing a suitable matrix and an excellent strategy to immobilize the enzyme [29]. Enzyme-based biosensors have tremendous applications in food, medicine, and environmental monitoring. Oxidoreductases and peroxidases are the most-reported enzymes in biosensors because they are very stable catalyzing oxide reduction reactions [31]. In this section, we will focus on glucose oxidase (GOx), horseradish peroxidase (HPR), and laccase (Figure 3); these enzymes have been successfully used for different applications in biosensors. 


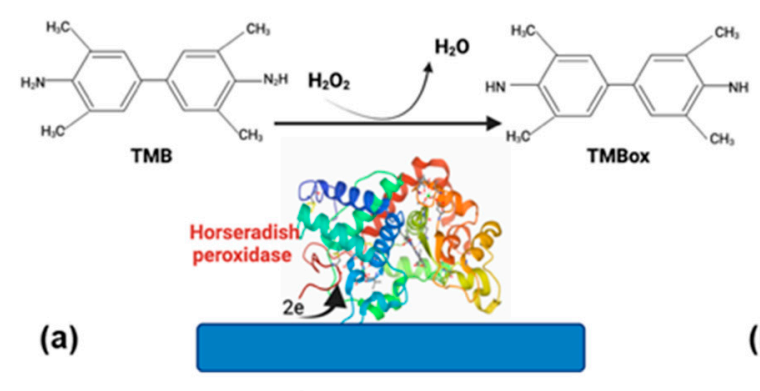

(b)

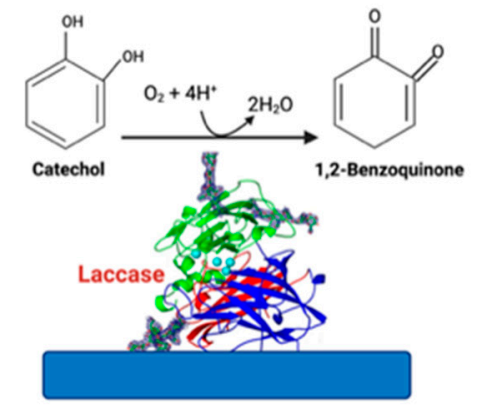

(c)

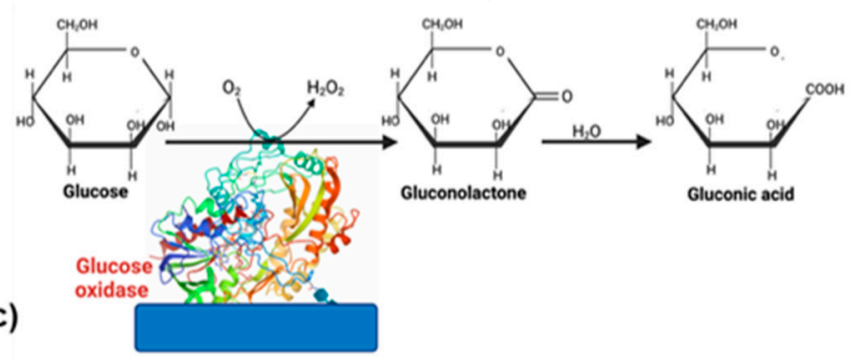

Figure 3. Enzymes commonly used in biosensors. (a) HRP, (b) laccase, and (c) glucose oxidase.

\subsection{Horseradish Peroxidase}

Horseradish peroxidase (HRP, EC 1.11.1.7) is an enzyme that belongs to the group of oxidoreductases. HRP is extensively distributed in nature, and its purification process is relatively simple. The principal source of extraction is the horseradish root. Some advantages reported are high activity and selectivity, resistance to inhibition by substances over a vast concentration, high operability, and reliability over a broad range of treatment conditions [32,33]. In addition, it can catalyze organic and inorganic substrates' oxidation by reacting with $\mathrm{H}_{2} \mathrm{O}_{2}$ and similar molecules [34]. Therefore, HPR is has been widely used in biosensors for $\mathrm{H}_{2} \mathrm{O}_{2}$ determination [30].

The detection mechanism of the $\mathrm{H}_{2} \mathrm{O}_{2}$ biosensor depends on the electrode (modified or not) and whether the mediator is used or not. The mediator facilities the electron transfer between enzymes and electrodes. In the presence of a mediator, the $\mathrm{H}_{2} \mathrm{O}_{2}$ in the solution is reduced by the HRP. On the other hand, the mediator is oxidized in the enzymatic reaction by itself. Moreover, the oxidized mediator is finally reduced on the electrode, with a change in the current. If the mediator is not present, the enzyme is converted to its oxidized form after being reduced at the electrode surface by direct electron transfer [35].

Hydrogen peroxide is an essential intermediate in enzymatic reactions. The detection of $\mathrm{H}_{2} \mathrm{O}_{2}$ is essential in medicine, food, and environmental assays (Table 1). As a result, the development of biosensors for $\mathrm{H}_{2} \mathrm{O}_{2}$ detection has been extensive [30]. Different materials have been reported to improve the response between the electrode and the HRP enzyme, for example, gold nanoparticles (AuNPs), cadmium sulfide, nanofibers, carbon nanomaterials. Carbon nanomaterials have unique properties, such as good biocompatibility, fast electron transfer, and excellent mechanical flexibility. Feizabadi et al. [30] immobilized HRP on a modified multi-walled carbon nanotube by $\gamma$ - aminobutyric acid (GABA) on a glassy carbon electrode. The covalent bonding formed between the enzyme and GABA increased the stability and reproducibility of the biosensor. Due to its characteristics as low detection $(0.13 \mu \mathrm{M})$ and extensive linear range $\left(0.2\right.$ to $281 \mu \mathrm{M}$ for $\left.\mathrm{H}_{2} \mathrm{O}_{2}\right)$, the biosensor could be used to quantify $\mathrm{H}_{2} \mathrm{O}_{2}$ in human plasma.

Da Silva Freires et al. [36] developed a biosensor based on copper (I) sulfide $\left(\mathrm{Cu}_{2} \mathrm{~S}\right)$ and HRP immobilized on a fluorine-doped tin oxide modified glass slide (FTO) for the determination of 1,4-dihydroxybenzene (DHB). The biosensor showed good selectivity for DHB, and good accuracy when DHB was determined in skin cream samples, presenting recovery percentages for the analyte in the samples between 99.89 and $100.70 \%$, suggesting a good accuracy of the proposed method. 
For cancer detection, exosomes can be an alternative as it is a non-invasive technique. Additionally, it is desirable for a cost-effective and instance detection in clinical diagnosis. Zeng et al. [37] developed a versatile biosensor to detect cancer-derived exomes (HepG2 cell-derived). HRP encapsulated DNA nanoflowers were the recognition elements and signal generation. A change of color was proportional to the concentration of exosomes. The system showed a satisfactory colorimetric response toward target exosomes within the working range from $5.0 \times 103$ to $5.0 \times 106$ particles $/ \mu \mathrm{L}$ at a low detection limit of $3.32 \times 103$ particles $/ \mu$ L. López-Marco et al. [38] used HRP in a 3Dprinted graphene/polylactic electrode and compared the detection of $\mathrm{H}_{2} \mathrm{O}_{2}$. The AuNPs facilitate and enhance electron transfer. However, they found that biosensors without AuNPs displayed better stability over time. The response of biosensors was evaluated in human serum.

Table 1. Horseradish peroxidase biosensors.

\begin{tabular}{|c|c|c|c|c|c|c|}
\hline Material & $\begin{array}{l}\text { Transduction } \\
\text { System }\end{array}$ & App & ication & $\begin{array}{c}\text { Linear Range } \\
\text { with a lineal } \\
\text { Correlation }\end{array}$ & $\begin{array}{l}\text { Limit of } \\
\text { Detection } \\
\text { (LOD) }\end{array}$ & Ref. \\
\hline $\begin{array}{l}\text { Glass plate covered with } \\
\text { fluorine-doped tin oxide } \\
\text { (FTO)Copper (I) sulfide } \\
\left(\mathrm{Cu}_{2} \mathrm{~S}\right) \text { and } \\
\text { fluorine-doped tin oxide } \\
\text { modified glass slide }\end{array}$ & Photoelectrochemica & al Health & $\begin{array}{c}1,4- \\
\text { dihydroxybenzene } \\
(\mathrm{DHB})\end{array}$ & $\begin{array}{l}10 \mathrm{nmol} \mathrm{L}^{-1} \text { up } \\
\text { to } 1 \mathrm{mmol} \mathrm{L}^{-1} \\
\quad(\mathrm{R}=0.998)\end{array}$ & $4.0 \mathrm{nmol} \mathrm{L}^{-1}$ & [36] \\
\hline $\begin{array}{c}\text { Encapsulated DNA } \\
\text { nanoflowers of } \\
\text { magnesium } \\
\text { pyrophosphate crystals }\end{array}$ & Colorimetric & Health & $\begin{array}{l}\text { Rapid screening } \\
\text { of cancer-derived } \\
\text { exosomes }\end{array}$ & $\begin{array}{c}5.0 \times 10^{3} \text { to } \\
5.0 \times 10^{6} \\
\text { particles } / \mu \mathrm{L} \\
\left(\mathrm{R}^{2}=0.9846\right)\end{array}$ & $\begin{array}{c}3.32 \times 10^{3} \\
\text { particles } / \mu \mathrm{L}\end{array}$ & [37] \\
\hline $\begin{array}{l}\text { Polydimethylsiloxane } \\
\text { (PDMS) deposited into a } \\
\text { polystyrene tube }\end{array}$ & Chemiluminescent & Health & $\begin{array}{c}\text { Quantification of } \\
\mathrm{H}_{2} \mathrm{O}_{2} \text { as the } \\
\text { oxidizing agent }\end{array}$ & $\begin{array}{c}0.06-10 \mu \mathrm{M} \\
\left(\mathrm{R}^{2}=0.999\right)\end{array}$ & $0.02 \mu \mathrm{M}$ & [4] \\
\hline $\begin{array}{l}\text { Modified multi walled } \\
\text { carbon nanotube by } \\
\gamma \text {-aminobutyric acid }\end{array}$ & Electrochemical & $\begin{array}{l}\text { Food, health, } \\
\text { environmental }\end{array}$ & $\begin{array}{l}\text { Detection of } \\
\text { hydrogen } \\
\text { peroxide }\end{array}$ & $\begin{array}{c}2.0 \times 10^{-7} \mathrm{M} \text { to } \\
2.81 \times 10^{-4} \mathrm{M} \\
\left(\mathrm{R}^{2}=0.998\right)\end{array}$ & $0.13 \mu \mathrm{M}$ & [30] \\
\hline $\begin{array}{c}\text { 3D-printed } \\
\text { graphene/polylactic } \\
\text { (PLA) electrode with } \\
\text { gold nanoparticles }\end{array}$ & Electrochemical & $\begin{array}{l}\text { Environmental } \\
\text { and biomedical } \\
\text { fields. }\end{array}$ & $\begin{array}{l}\text { Hydrogen } \\
\text { peroxide } \\
\text { detection }\end{array}$ & $\begin{array}{l}25-100 \mu \mathrm{M} \\
(\mathrm{R}=0.996)\end{array}$ & $11.1 \mu \mathrm{M}$ & [38] \\
\hline $\begin{array}{l}\text { HRP-encapsulated } \\
\text { protein nanoparticles in } \\
\text { an Au electrode surface }\end{array}$ & Electrochemical & $\begin{array}{c}\text { Clinical } \\
\text { applications }\end{array}$ & $\begin{array}{l}\text { Hydrogen } \\
\text { peroxide } \\
\text { detection }\end{array}$ & $0.01-100 \mu \mathrm{M}$ & $0.01 \mu \mathrm{M}$ & [39] \\
\hline $\begin{array}{l}\text { Modified platinum } \\
\text { electrode covered with } \\
\text { poly(4,7-bis(5- } \\
\text { bromothiophen-2-yl) } \\
\text { benzothiadiazole) }\end{array}$ & Electrochemical & Health & $17 \beta$ - estradiol & $\begin{array}{c}0.1 \text { to } 200 \mathrm{mM} \\
\left(\mathrm{R}^{2}=0.99\right)\end{array}$ & $105 \mathrm{nM}$ & [40] \\
\hline $\begin{array}{c}\text { Tungsten microwire } \\
\text { modified with AuNPs } \\
\text { and 3-mercaptopropionic } \\
\text { acid }\end{array}$ & Electrochemical & Health & $\begin{array}{l}\text { Determination of } \\
\text { hydrogen } \\
\text { peroxide }\end{array}$ & $\begin{array}{c}5 \mathrm{nM} \text { to } 5 \mu \mathrm{M} \\
(\mathrm{R}=0.999)\end{array}$ & 800 pM & [41] \\
\hline $\begin{array}{l}\text { Modified acrylic } \\
\text { microspheres }\end{array}$ & Electrochemical & Food & $\begin{array}{l}\text { Chilli hotness } \\
\text { determination }\end{array}$ & $\begin{array}{c}0.75-24.94 \mu \mathrm{M} \\
\left(\mathrm{R}^{2}=0.992\right)\end{array}$ & $0.39 \mu \mathrm{M}$ & [42] \\
\hline
\end{tabular}




\subsection{Glucose Oxidase}

Nowadays, measuring blood glucose has been widely studied due to its relevance for health care [8]. Glucose oxidase (GOx) is the principal enzyme used for the devices of glucose monitoring. It is a glycoprotein that possesses orthophosphates proteins. This enzyme has unique properties such as dispersibility in water, resistance to precipitation, and stability. All these advantages make GOx efficient for glucose monitoring in blood or saliva [8]. The continuous monitoring of glucose is vital in diabetes mellitus disease. Therefore, the production of a simple, cost-effective, accurate, and rapid sensor is essential. GOx has still been used for glucose detection due to its reliable stability and substrate specificity. The principle of its operation is the enzymatic oxidation of glucose and after the electrochemical oxidation of $\mathrm{H}_{2} \mathrm{O}_{2}$ [43].

Electrochemical biosensors have been used to detect glucose using GOx (Table 2) [44]. The GOx enzyme converts the glucose to gluconic-d-lactone by reducing the flavin adenine dinucleotide (FAD) to $\mathrm{FADH}_{2}$. Then, $\mathrm{H}_{2} \mathrm{O}_{2}$ is produced due to $\mathrm{FADH} 2$ deoxidized by dissolved $\mathrm{O}_{2}$. Subsequently, the $\mathrm{H}_{2} \mathrm{O}_{2}$ is oxidized to $\mathrm{O}_{2}$ when a working potential is applied, and the electric current produced in the biosensor is proportionate to the glucose concentration [45]. The incorporation of nanomaterials as biosensor components has enhanced their performance. Bagyalakshmi et al. [44] prepared $\mathrm{ZnO}$ nanorods with chitosan. GOx was immobilized by the adsorption method. The $\mathrm{ZnO}$ nanorods were a successful platform for the immobilization of GOx due to their high surface area and displayed a good performance for displaying glucose. The use of carbon nanotubes in glucose biosensors have been improved the enzyme stability and specificity. Jayakumar et al. [46] reported an adsorbed osmium-based redox polymer crosslinked with GOx. It was possible to use less nanoconjugate due to the covalent bond between GOx and multiwalled carbon nanotubes (MWCNTs). Green approaches also have been made for the development of glucose biosensors. Yang et al. [9] developed an enzyme electrode based on AuNPs, PNE, and GOx for glucose detection by a green method. The biosensor presented high sensitivity to glucose and high response of fewer than $3 \mathrm{~s}$. Redox mediator p-benzoquinone was added to enhance the linear detection range and sensitivity

Table 2. Glucose oxidase biosensors.

\begin{tabular}{|c|c|c|c|c|c|c|}
\hline Material & $\begin{array}{l}\text { Transduction } \\
\text { System }\end{array}$ & & ation & $\begin{array}{l}\text { Linear Range } \\
\text { with a Lineal } \\
\text { Correlation }\end{array}$ & $\begin{array}{l}\text { Limit of } \\
\text { Detection } \\
\text { (LOD) }\end{array}$ & Ref. \\
\hline $\begin{array}{l}\mathrm{ZnO} \text { nanorods with } \\
\text { chitosan }\end{array}$ & Electrochemical & Health & $\begin{array}{c}\text { Glucose } \\
\text { determination }\end{array}$ & $\begin{array}{c}10 \mu \mathrm{M} \text { to } 40 \mu \mathrm{M} \\
(\mathrm{R}=0.9998)\end{array}$ & & [44] \\
\hline $\begin{array}{l}\text { Multi-walled carbon } \\
\text { nanotubes and osmium } \\
\text { redox polymer }\end{array}$ & Electrochemical & Health & $\begin{array}{c}\text { Glucose } \\
\text { determination }\end{array}$ & & & [46] \\
\hline $\begin{array}{l}\text { Au nanoparticles } \\
\text { (AuNPs) and } \\
\text { polynorepinephrine } \\
\text { (PNE) }\end{array}$ & Electrochemical & Health & $\begin{array}{c}\text { Glucose } \\
\text { determination } \\
\text { in human blood } \\
\text { serum samples }\end{array}$ & $\begin{array}{c}0.003 \mathrm{mM} \text { to } \\
3.43 \mathrm{mM} \\
\left(\mathrm{R}^{2}=0.9987\right)\end{array}$ & $1.34 \mu \mathrm{M}$ & [9] \\
\hline $\begin{array}{l}\text { Glassy carbon } \\
\text { electrode with blend } \\
\text { nanofibers of poly } \\
\text { (vinyl alcohol) and } \\
\text { poly(ethyleneimine) }\end{array}$ & Electrochemical & Health & $\begin{array}{l}\text { Glucose in real } \\
\text { samples }\end{array}$ & $\begin{array}{c}10 \text { to } \\
30 \mathrm{mmol} \mathrm{L}^{-1} \\
\left(\mathrm{R}^{2}=0.971\right)\end{array}$ & $0.3 \mathrm{mmol} \mathrm{L}^{-1}$ & [16] \\
\hline $\begin{array}{l}\text { Screen-printed carbon } \\
\text { electrode with } \\
\text { platinum nanoparticles } \\
\text { electrodeposited on } \\
\text { Poly(Azure A) }\end{array}$ & Electrochemical & Food & $\begin{array}{c}\text { Glucose } \\
\text { quantification } \\
\text { in real samples }\end{array}$ & $20 \mu \mathrm{M}-2.3 \mathrm{mM}$ & $7.6 \mu \mathrm{M}$ & [47] \\
\hline
\end{tabular}




\subsection{Laccase}

Laccase (benzenediol: oxidoreductase, E.C. 1.10.3.2) is a multi-copper oxidase considered a green catalyst due to combines the four-electron reduction of dioxygen to water with the one-electron oxidation of four substrate molecules [48,49]. Laccase can be produced by insects, plants, bacteria, or fungi. It is considered a suitable enzyme due to its excellent catalytic properties $[50,51]$. The substrate range is vast, and they can oxidase different compounds, resulting in the application of numerous biotechnological applications such as environment, food, and biosensors (Table 3) [52].

The laccase biosensor is of the third-generation type. Due to direct electron transfer between the electrode and enzyme, there is no need for a mediator. Laccases are immobilized on the electrode's surface, and they are oxidized by oxygen and then are reduced by the substrate acting as electron donors for the oxidized form of the enzyme. A reduction current will be observed to reduce the products, which is proportional to their concentration. Unlike peroxidases, laccase-based biosensors only need oxygen and are already present in the solutions, so it is unnecessary to $\mathrm{H}_{2} \mathrm{O}_{2}$ for its catalysis [53].

Laccase biosensors have been used widely for dopamine detection. However, even when some analytes' determination as dopamine has been studied extensively, novel techniques and approaches have been developed. Wardak et al. [10] constructed a laccase-based biosensor constructed by Soft Plasma Polymerization technique for dopamine detection. This technique enhances the sensitivity, and it was proved for pharmaceutical samples with satisfactory results. Furthermore, the use of polysaccharides has been explored. An exopolysaccharide (EPS) named botryosphaeran, and MWCNT were used to immobilize laccase on a glassy carbon electrode to detect dopamine. Even in the presence of other molecules as uric acid, the biosensor could determine the presence of dopamine [54]. Additionally, the fluorescence principle has been used for dopamine detection. Sangubotla and Kim [55] developed a fiber-optic biosensor with carbon dots and laccase. This material presents excellent features such as hydrophobicity, tunable photoluminescence, and biocompatibility.

Table 3. Laccase biosensors.

\begin{tabular}{|c|c|c|c|c|c|c|}
\hline Material & $\begin{array}{l}\text { Transduction } \\
\text { System }\end{array}$ & App & ation & $\begin{array}{c}\text { Linear Range with } \\
\text { a Lineal } \\
\text { Correlation }\end{array}$ & Limit of Detection & Ref. \\
\hline $\begin{array}{l}\text { Laccase hybrid } \\
\text { microflowers } \\
\text { synthesized with } \\
\mathrm{Cu}_{3}\left(\mathrm{PO}_{4}\right)_{2} \cdot 3 \mathrm{H}_{2} \mathrm{O}\end{array}$ & Optical & $\begin{array}{l}\text { Health, clinical } \\
\text { diagnosis } \\
\text { application }\end{array}$ & $\begin{array}{l}\text { Quantification of } \\
\text { epinephrine }\end{array}$ & $\begin{array}{c}1-400 \mu \mathrm{M} \\
\left(\mathrm{R}^{2}=0.999\right)\end{array}$ & $0.6 \mu \mathrm{M}$ & [56] \\
\hline $\begin{array}{c}\text { Carbon dots } \\
\text { bio functionalized } \\
\text { with 3-(aminopropyl)- } \\
\text { triethoxysilane }\end{array}$ & Optical & $\begin{array}{l}\text { Health. Clinical } \\
\text { diagnosis } \\
\text { application. } \\
\text { Diagnosis of } \\
\text { Alzheimer's and } \\
\text { Parkinson's } \\
\text { diseases. }\end{array}$ & $\begin{array}{l}\text { Detection of } \\
\text { dopamine }\end{array}$ & $\begin{array}{c}0-30 \mu \mathrm{M} \\
\left(\mathrm{R}^{2}=0.995\right)\end{array}$ & $41.2 \mathrm{nM}$ & [55] \\
\hline $\begin{array}{l}\text { Multi-walled Carbon } \\
\text { Nanotubes modified } \\
\text { glassy carbon } \\
\text { electrode }\end{array}$ & Electrochemical & $\begin{array}{l}\text { Diagnosis of } \\
\text { Alzheimer's and } \\
\text { Parkinson's } \\
\text { diseases. }\end{array}$ & $\begin{array}{l}\text { Dopamine } \\
\text { detection }\end{array}$ & $\begin{array}{l}0.1 \mu \mathrm{mol} / \mathrm{dm}^{3} \text { to } \\
10 \mu \mathrm{mol} / \mathrm{dm}^{3} \text { and } \\
\text { from } 10 \mu \mathrm{mol} / \mathrm{dm}^{3} \\
\text { to } 50 \mu \mathrm{mol} / \mathrm{dm}^{3}\end{array}$ & $\begin{array}{c}3.63 \mu \mathrm{A} \cdot \mathrm{dm}^{3} / \mu \mathrm{mol} \\
\text { and } 1.33 \mu \mathrm{A} \cdot \mathrm{dm}^{3} / \mu \mathrm{mol}\end{array}$ & [10] \\
\hline $\begin{array}{c}\mathrm{Fe}_{3} \mathrm{O}_{4} @ \mathrm{SiO}_{2} \\
\text { microspheres } \\
\text { stabilized onto glassy } \\
\text { carbon electrode }\end{array}$ & Electrochemical & Health & $\begin{array}{l}\text { Dopamine } \\
\text { detection }\end{array}$ & $\begin{array}{l}1.5-75 \mu \mathrm{mol} \mathrm{L}{ }^{-1} \\
(\mathrm{R}=0.9980)\end{array}$ & $0.177 \mu \mathrm{mol} \mathrm{L}-1$ & [57] \\
\hline
\end{tabular}


Table 3. Cont.

\begin{tabular}{|c|c|c|c|c|c|c|}
\hline Material & $\begin{array}{l}\text { Transduction } \\
\text { System }\end{array}$ & \multicolumn{2}{|c|}{ Application } & $\begin{array}{c}\text { Linear Range with } \\
\text { a Lineal } \\
\text { Correlation }\end{array}$ & Limit of Detection & Ref. \\
\hline $\begin{array}{c}\text { electrode layered with } \\
\text { multi-walled carbon } \\
\text { nanotubes using a } \\
\text { film of } \\
\text { botryosphaeran }\end{array}$ & Electrochemical & Health & $\begin{array}{l}\text { Dopamine and } \\
\text { spironolactone } \\
\text { detection }\end{array}$ & $\begin{array}{c}2.99-38.5 \mu \mathrm{mol} \mathrm{L}^{-1} \\
\left(\mathrm{R}^{2}=0.995\right)\end{array}$ & $0.127 \mu \mathrm{mol} \mathrm{L}{ }^{-1}$ & {$[54]$} \\
\hline $\begin{array}{c}\text { Carbon paper } \\
\text { electrodes with } \\
\text { layered } \\
\text { two-dimensional } \\
\text { molybdenum } \\
\text { disulfide }\left(\mathrm{MoS}_{2}\right) \text { in } \\
\text { flowers }\left(\mathrm{MoS}_{2}-\mathrm{F}\right) \text { and } \\
\text { ribbons }\left(\mathrm{MoS}_{2}-\mathrm{R}\right)\end{array}$ & Electrochemical & $\begin{array}{l}\text { Synthetic urine } \\
\text { sample }\end{array}$ & $\begin{array}{l}\text { Dopamine } \\
\text { detection }\end{array}$ & $\begin{array}{l}0.1 \text { to } 0.5 \mu \mathrm{M} \text { and } \\
\text { from } 1 \text { to } 5 \mu \mathrm{M} \\
\left(\mathrm{R}^{2}=0.993\right)\end{array}$ & $10 \mathrm{nM}$ & [58] \\
\hline $\begin{array}{c}\text { 6,9-bis(4- } \\
\text { hexylthiophen-2-yl)- } \\
11 \mathrm{H}- \\
\text { indeno[2,1- } \\
\text { b]quinoxalin-11-one } \\
\text { (M1)) polymerized on } \\
\text { electrode surface. }\end{array}$ & Electrochemical & $\begin{array}{l}\text { Environmental } \\
\text { applications }\end{array}$ & Catechol in water & $\begin{array}{c}005-0.175 \mathrm{mM} \\
\left(\mathrm{R}^{2}=0.994\right)\end{array}$ & $9.86 \mu \mathrm{M}$ & [59] \\
\hline $\begin{array}{l}\text { Screen-printed carbon } \\
\text { electrodes modified } \\
\text { with carboxyl } \\
\text { functionalized } \\
\text { multi-wallet carbon } \\
\text { nanotubes }\end{array}$ & Electrochemical & $\begin{array}{l}\text { Environmental } \\
\text { application }\end{array}$ & $\begin{array}{l}\text { Phenolics } \\
\text { detection }\end{array}$ & & & [14] \\
\hline
\end{tabular}

\subsection{Other Enzymes}

Another commonly used enzyme in biosensors is the tyrosinase, a polyphenol oxidase (Table 4). Tyrosinase is a natural enzyme that may be produced by bacteria, fungi, plants, and mammals. This enzyme catalyzes the oxidation of various phenolics compounds, and their reaction products could be detected by voltamperometric biosensors [60]. The versatility of this enzyme allows it used in the environmental, medical and food field. García-Guzmán et al. [61] developed a biosensor index in beers and wines using caffeic acid as the reference. The biosensor displayed good analytical performance. Additionally, tyrosinase was used in the environmental field for the construction of a biosensor for detection of bisphenol A in water [62]. Alkaline phosphatase (ALP) is extensively used in the diagnosis and monitoring of many diseases. This enzyme catalyzes the dephosphorilation of proteins, biomolecules and nuclei acids. A higher level of ALP is related with tumors, biliary obstruction and diabetes [63]. Moreover, it can be used to detect organophosphate pesticide through catalyzes. Stéfanne e Silva et al. [64] immobilized ALP onto a modified non-commercial, low cost and nonrefundable pencil carbon graphite with three polymers derived from hydroxybenzoic acids for pesticide detection. Urease is an enzyme used for the urea detection, its levels are directly related to the protein intake and nitrogen metabolism in humans. Kim et al. [65] developed a portable biosensor for real time monitoring of the flow of physiological fluids on a porous polytetrafluoethylene. 
Table 4. Other enzymes commonly used in biosensors.

\begin{tabular}{|c|c|c|c|c|c|c|}
\hline Enzyme & $\begin{array}{l}\text { Transduction } \\
\text { System }\end{array}$ & \multicolumn{2}{|c|}{ Application } & \multirow{2}{*}{$\begin{array}{c}\begin{array}{c}\text { Linear Range } \\
\text { with a Lineal } \\
\text { Correlation }\end{array} \\
0.1-38 \mu \mathrm{M}\end{array}$} & \multirow{2}{*}{$\begin{array}{c}\begin{array}{c}\text { Limit of } \\
\text { Detection } \\
\text { (LOD) }\end{array} \\
0.067 \mu \mathrm{M}\end{array}$} & \multirow{2}{*}{$\begin{array}{l}\text { Ref. } \\
{[66]}\end{array}$} \\
\hline \multirow[t]{2}{*}{ Lipase } & Electrochemical & $\begin{array}{l}\text { Environmental } \\
\text { application }\end{array}$ & $\begin{array}{l}\text { Methyl } \\
\text { parathion } \\
\text { detection }\end{array}$ & & & \\
\hline & Optical & $\begin{array}{c}\text { Health } \\
\text { application }\end{array}$ & $\begin{array}{c}\text { Triglycerides } \\
\text { detection }\end{array}$ & $100-400 \mathrm{mg} / \mathrm{dL}$ & $15 \mathrm{mg} / \mathrm{dL}$ & [67] \\
\hline Urease & Electrochemical & $\begin{array}{c}\text { Health } \\
\text { application }\end{array}$ & Urea detection & $1.2-20 \mathrm{mM}$ & $1.1 \mathrm{mM}$ & [65] \\
\hline \multirow{4}{*}{ Tyrosinase } & Electrochemical & $\begin{array}{l}\text { Environmental } \\
\text { application }\end{array}$ & $\begin{array}{c}\text { Bisphenol } \\
\text { detection }\end{array}$ & $0.05-20 \mu \mathrm{M}$ & $0.011 \mu \mathrm{M}$ & [68] \\
\hline & Electrochemical & $\begin{array}{c}\text { Food } \\
\text { applications }\end{array}$ & $\begin{array}{l}\text { Caffeic acid } \\
\text { (reference } \\
\text { polyphenol } \\
\text { indices in beers } \\
\text { and wines) }\end{array}$ & $10-300 \mu \mathrm{M}$ & $4.33 \mu \mathrm{M}$ & [61] \\
\hline & Electrochemical & $\begin{array}{l}\text { Environmental } \\
\text { applications }\end{array}$ & $\begin{array}{l}\text { Bisphenol } \\
\text { detection }\end{array}$ & $\begin{array}{l}5 \times 10^{-8}-2 \times \\
10^{-6} \mathrm{~mol} \mathrm{~L}^{-1}\end{array}$ & $12 \mathrm{nM} \mathrm{L}^{-1}$ & {$[62]$} \\
\hline & Electrochemical & $\begin{array}{c}\text { Food } \\
\text { applications }\end{array}$ & $\begin{array}{c}\text { Benzoic acid } \\
\text { detection }\end{array}$ & & $0.4 \mu \mathrm{mol} \mathrm{L}-1$ & [69] \\
\hline $\begin{array}{c}\text { Lactate } \\
\text { dehydrogenase }\end{array}$ & Electrochemical & $\begin{array}{c}\text { Health } \\
\text { applications }\end{array}$ & $\begin{array}{l}\text { Pyruvate } \\
\text { detection }\end{array}$ & $\begin{array}{c}5 \times 10^{3}-1.4 \times \\
10^{5} \mathrm{nM}\end{array}$ & $8.69 \mathrm{nM}$ & {$[70]$} \\
\hline $\begin{array}{c}\text { Alkaline } \\
\text { phosphatase }\end{array}$ & Electrochemical & $\begin{array}{l}\text { Environmental } \\
\text { applications }\end{array}$ & $\begin{array}{l}\text { Pesticide } \\
\text { detection }\end{array}$ & & $20 \mu \mathrm{M}$ & [64] \\
\hline
\end{tabular}

\section{Bi-Enzyme Biosensors}

Multi-analyte biosensors can offer the opportunity to perform rapid and cost-effective analysis with a unique sample. Sensitive techniques for multi-analyte detection have become essential in the environment, medical care, food, anti-terrorism, etc. Biosensors for multi-analyte determination do not require complicated and time-consuming procedures and expensive test costs. Additionally, reduction in the physical size of the device is desired, having one electrode with two or more enzymes reduce the space and materials used. Consequently, the biosensors for multianalyte determination are inexpensive. Therefore, several types of research have focused on developing multi-analyte sensors conserving speed, specificity, and sensitivity (Table 5) [71]. Nevertheless, it is essential to find the conditions where all the enzymes have adequate activity and stability and consider that one of the products may have enzyme inactivating effects. Thus, the optimization of the process will be complex because it is necessary to find the conditions where all the enzymes can have good activity for the reaction. Co-immobilization is when two or more enzymes are confined in the same space [72]. It has been proved to be an successful strategy for ordered multi-enzyme immobilization, which can control and enhance the cascade enzymatic reaction rates via adjusting the immobilized sequence [73]. The co-immobilization could use multiple analyte detection of multi-enzymes on an electrode [71]. For example, a bi-enzyme modified electrode with HRP and GOx immobilized by entrapment in poly(noradrenalin) demonstrated to be effective in the monitoring multi-analyte $\left(\mathrm{H}_{2} \mathrm{O}_{2}, \mathrm{Cr}\right.$ (III), glucose, and $\mathrm{Cr}(\mathrm{VI})$ ). This biosensor demonstrates high sensitivity, low LOD, and good selectivity to detect the four analytes [72]. Yokus et al. [74] develop a multiple analyte detection for glucose and lactose. This system had a comparable performance and could quantify and discriminate between two metabolic biomarkers present in sweat. 
Multi-enzymatic reactions or cascade reactions occurs in a biosensor with two or more enzymes [75]. The simultaneous use of enzymes has positive effects on reaction performance in cascade reactions. In this process, the product of one enzyme is the other enzyme substrate, as shown in Figure 4. Additionally, co-immobilized enzymes could accelerate initial reaction [72] and enhance the sensitivity of enzyme-biosensors. For example, in the case of glucose biosensors with GOx, it has been shown that an alternative to increasing the biosensor performance (low sensitivity and eliminate interference problems) is the construction of bi-enzymatic peroxidase/oxidase biosensors. In this system $\mathrm{H}_{2} \mathrm{O}_{2}$ generated for glucose oxidation is reduced by HRP. Additionally, it has been proved the enhancement of sensitivity and avoidance. This system has been proved to enhance the sensitivity and prevention of $\mathrm{H}_{2} \mathrm{O}_{2}$ accumulation, which avoids the inactivation of GOx [76]. Additionally, the addition of carbon nanotubes improved the efficiency of biosensors because they facilitated electron transfer. HRP and GOx were co-assembled onto carbon nanotubes modified glass carbon electrodes. HRP provided a biocompatibility microenvironment for the GOx, and the carbon nanotubes facilitated electron transfer. As a result, the biosensor detected glucose based on the consumption of $\mathrm{O}_{2}$. Due to the supporting matrix and the cooperation of both enzymes, electrochemical detection of glucose could be achieved with low LOD [77].

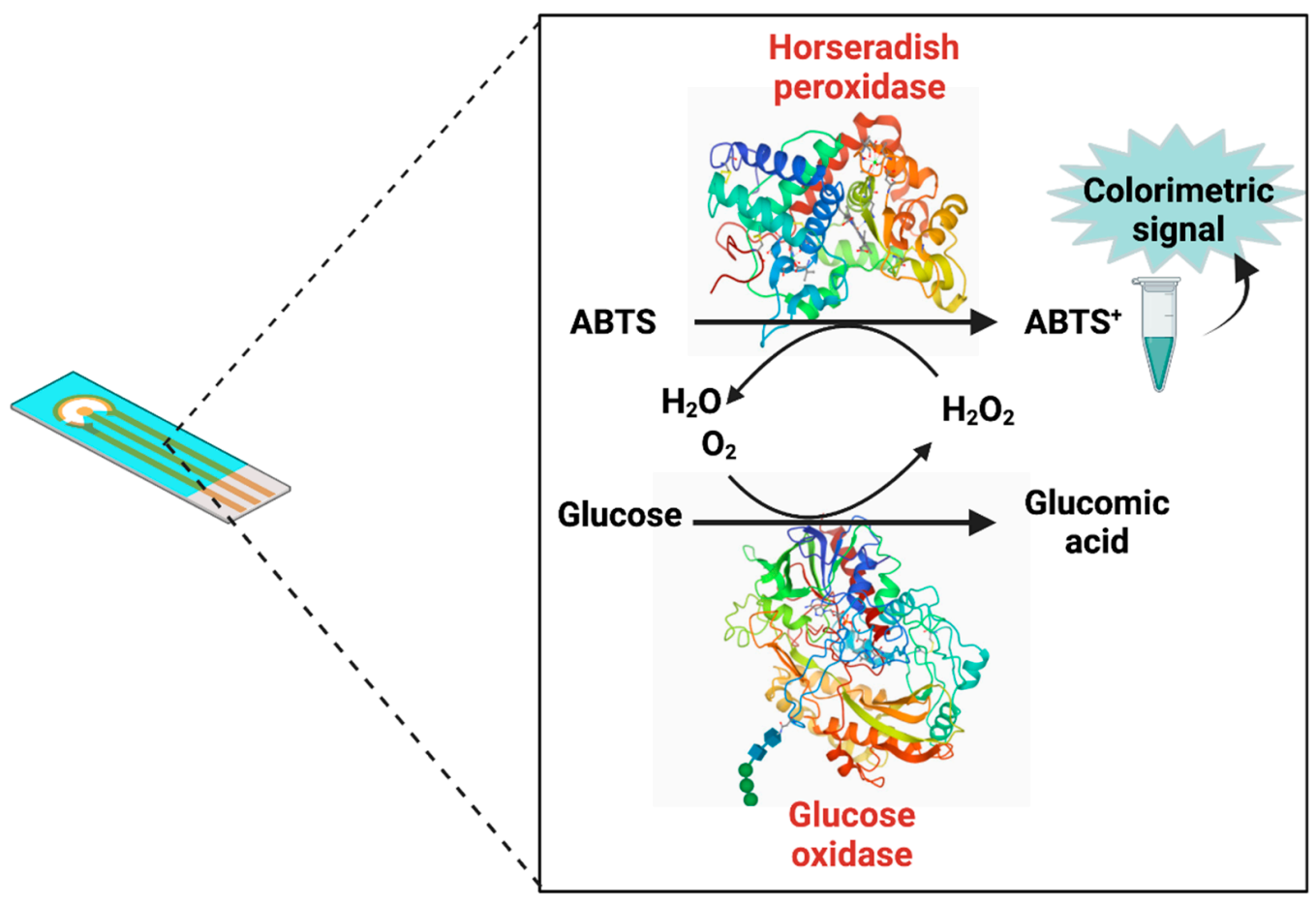

Figure 4. Schematic representation of a bi-enzymatic biosensor. 
Table 5. Bi-enzyme systems for biosensors, specifications, and applications.

\begin{tabular}{|c|c|c|c|c|c|c|}
\hline Enzymes & $\begin{array}{l}\text { Transduction } \\
\text { System }\end{array}$ & Material & Application & $\begin{array}{c}\text { Detection Range } \\
\text { with a Linear } \\
\text { Correlation }\end{array}$ & $\begin{array}{l}\text { Limit of Detection } \\
\text { (LOD) }\end{array}$ & Ref. \\
\hline $\begin{array}{l}\text { Glucose oxidase } \\
\text { and horseradish } \\
\text { peroxidase }\end{array}$ & Electrochemical & $\begin{array}{c}\text { Carbon } \\
\text { nanotubes } \\
\text { modified glassy } \\
\text { carbon electrode }\end{array}$ & Glucose detection & $\begin{array}{l}0.022 \text { to } 7.0 \mathrm{mM} \\
\quad(\mathrm{R}=0.998)\end{array}$ & $7 \mu \mathrm{M}$ & [77] \\
\hline $\begin{array}{l}\text { Glucose oxidase } \\
\text { and horseradish } \\
\text { peroxidase }\end{array}$ & Electrochemical & $\begin{array}{l}\text { Polynoradrenalin/ } \\
\text { Polyaniline } \\
\text { electrode }\end{array}$ & $\begin{array}{c}\text { Glucose } \\
\mathrm{Cr}(\mathrm{III}) \\
\mathrm{Cr}(\mathrm{VI}))\end{array}$ & $\begin{array}{c}0.50 \mu \mathrm{M}-0.42 \mathrm{mM} \\
0.01-3.8 \mu \mathrm{M} \\
0.50-6.0 \mathrm{nM}\end{array}$ & $\begin{array}{l}0.08 \mu \mathrm{M} \\
0.20 \mathrm{nM}\end{array}$ & [71] \\
\hline $\begin{array}{l}\text { HRP and lactate } \\
\text { oxidase }\end{array}$ & Electrochemical & $\begin{array}{l}\text { Electrochemical } \\
\text { lactate biosensor }\end{array}$ & $\begin{array}{c}\text { Determination of } \\
\text { lactate }\end{array}$ & $\begin{array}{c}30.4 \mu \mathrm{M} \\
-243.9 \mu \mathrm{M} \\
\end{array}$ & $22.6 \mu \mathrm{M}$ & {$[78]$} \\
\hline $\begin{array}{l}\text { Laccase and } \\
\text { tyrosinase }\end{array}$ & Electrochemical & $\begin{array}{l}\text { Graphite screen } \\
\text { printed electrode } \\
\text { modified with } \\
\text { ferrocene }\end{array}$ & $\begin{array}{c}\text { Phenol } \\
\text { Gallic acid } \\
\text { Caffeic acid } \\
\text { Catechin }\end{array}$ & $\begin{array}{l}\left(\mathrm{R}^{2}=0.9994\right) \\
\left(\mathrm{R}^{2}=0.9977\right) \\
\left(\mathrm{R}^{2}=0.9992\right) \\
\left(\mathrm{R}^{2}=0.9930\right)\end{array}$ & $\begin{array}{c}2 \mu \mathrm{M} \\
50 \mu \mathrm{M} \\
24 \mu \mathrm{M} \\
40 \mu \mathrm{M}\end{array}$ & [79] \\
\hline $\begin{array}{l}\text { Alcohol oxidase } \\
\text { and horseradish } \\
\text { peroxidase }\end{array}$ & Electrochemical & $\begin{array}{l}\text { Carbon nanotube } \\
\text { matrix }\end{array}$ & $\begin{array}{l}\text { Methyl salicylate } \\
\text { determination in } \\
\text { plants }\end{array}$ & & $\begin{array}{c}22.95 \mu \mathrm{M} \text { and } \\
0.98 \mu \mathrm{M}\end{array}$ & [80] \\
\hline $\begin{array}{l}\text { D-amino acid } \\
\text { oxidase and } \\
\text { horseradish } \\
\text { peroxidase }\end{array}$ & Electrochemical & $\begin{array}{l}\text { Multi-walled } \\
\text { carbon nanotubes } \\
\text { and gold } \\
\text { nanoparticles } \\
\text { modified } \\
\text { screen-printed } \\
\text { electrode }\end{array}$ & $\begin{array}{l}\text { The total content } \\
\text { of D-amino acids }\end{array}$ & $\begin{array}{l}0.020 \text { to } 2.0 \mathrm{mM} \\
(\mathrm{R}=0.994)\end{array}$ & $18 \mu \mathrm{m}$ & [81] \\
\hline $\begin{array}{l}\text { d-amino acid } \\
\text { oxidase and } \\
\text { hemoglobin }\end{array}$ & Electrochemical & $\begin{array}{l}\mathrm{MnO}_{2} \\
\text { nanoparticles } \\
\text { enriched poly } \\
\text { thiophene }\end{array}$ & Dopamine & $\begin{array}{l}0.04-9.0 \mu \mathrm{M} \\
\left(\mathrm{R}^{2}=0.994\right)\end{array}$ & $\begin{array}{c}12.801 \mu \mathrm{A} / \mu \mathrm{M} \text { and } \\
41 \mathrm{nM}\end{array}$ & [82] \\
\hline $\begin{array}{l}\text { Cholesterol } \\
\text { oxidase and } \\
\text { horseradish } \\
\text { peroxidase }\end{array}$ & Electrochemical & $\begin{array}{l}\text { Poly(thionine)- } \\
\text { modified glassy } \\
\text { carbon electrode }\end{array}$ & Cholesterol & $\begin{array}{c}25-125 \mu \mathrm{M} \\
(\mathrm{R}=0.99)\end{array}$ & $6.3 \mu \mathrm{M}$ & [83] \\
\hline $\begin{array}{l}\text { Acetylcholinesterase } \\
\text { and choline } \\
\text { oxidase }\end{array}$ & Optical & Gold nanorods & $\begin{array}{l}\text { Dichlorvos } \\
\text { Demeton }\end{array}$ & $\begin{array}{c}0.1 \text { to } 500 \mu \mathrm{g} / \mathrm{L} \\
\left(\mathrm{R}^{2}=0.963\right) \\
1 \text { to } 500 \mu \mathrm{g} / \mathrm{L} \\
\left(\mathrm{R}^{2}=0.963\right)\end{array}$ & $\begin{array}{c}8.1 \times 10^{-3} \mu \mathrm{g} / \mathrm{L} \\
0.32 \mu \mathrm{g} / \mathrm{L}\end{array}$ & [84] \\
\hline $\begin{array}{l}\text { Glucose oxidase } \\
\text { and lactate } \\
\text { oxidase }\end{array}$ & Electrochemical & $\begin{array}{l}\text { Flexible electrode } \\
\text { array with gold } \\
\text { nanoparticles and } \\
\text { Prussian blue }\end{array}$ & $\begin{array}{c}\text { Glucose and } \\
\text { lactate detection }\end{array}$ & $\begin{array}{c}60 \mu \mathrm{M}-1000 \mu \mathrm{M} \\
\text { (glucose) } \\
5 \underset{\text { (lactate) }}{\mathrm{mM}-20 \mathrm{mM}}\end{array}$ & & {$[74]$} \\
\hline $\begin{array}{l}\text { Urease and } \\
\text { penicillinase }\end{array}$ & Electrochemical & $\mathrm{Ta}_{2} \mathrm{O}_{5}$ & $\begin{array}{l}\text { Urea and } \\
\text { penicillin } \\
\text { detection }\end{array}$ & $\begin{array}{c}1 \mathrm{mM}-25 \mathrm{mM} \text { (urea) } \\
0.1 \mathrm{mM}-5 \mathrm{mM} \\
\text { (penicillin) }\end{array}$ & & [85] \\
\hline
\end{tabular}

\section{Nanozyme Biosensors}

Even when enzymatic reactions are highly effective and selective, natural enzymes are difficult to obtain in large quantities, and their catalytic activity is affected by the external environment. Therefore, the study of alternatives to solve the weaknesses of natural enzymes has increased [86]. Nanozymes are nanomaterials that possess unique physicochemical properties and mimic natural enzymes properties (Figure 5) [87]. Significant progress has been made since the report of $\mathrm{Zn}^{2+-}$ triazacyclonane-functionalized gold nanoparticles with intrinsic peroxidase-like activity due to the rapid development of nanomaterials [88]. In addition, nanozymes offer high structural durability, stability, compatibility with biological materials, remarkable catalytic activity, and material variety. As a result, they are widely used in biosensors for medical diagnosis and environmental monitoring, and they have a huge potential because they are fast, sensitive, efficient, and cheap [89]. Additionally, another exciting advantage of nanozymes is their size/composition-dependent activity. This makes the design of materials with a wide range of catalytic activity possible only by changing the shape, structure, and composition. Besides, their self-assembling ability makes it easier to incorporate biological components into the structure [17]. However, to develop a 
comparison with the biosensors analyzed before, this section will focus on the nanozymes that mimic the activity of peroxidase, glucose oxidase, and laccase (Table 6) [90-101].

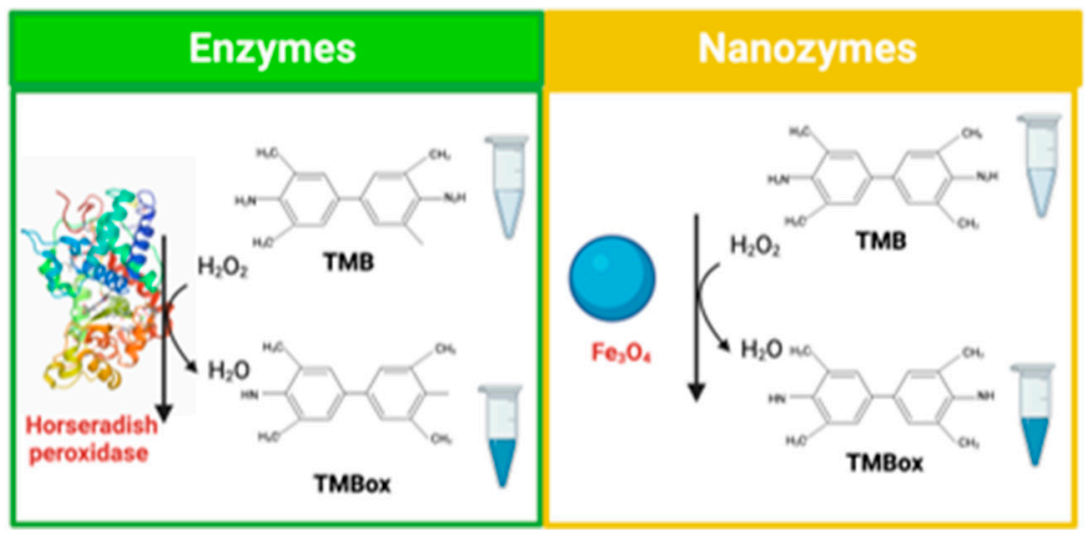

Figure 5. Catalytic action of an enzyme and nanozyme.

Table 6. Nanozymes (enzyme-like activity) specifications and applications.

\begin{tabular}{|c|c|c|c|c|c|c|}
\hline Nanozyme & $\begin{array}{l}\text { Transduction } \\
\text { System }\end{array}$ & Material & Application & $\begin{array}{l}\text { Detection Range } \\
\text { with a Linear } \\
\text { Correlation }\end{array}$ & $\begin{array}{l}\text { Limit of } \\
\text { Detection }\end{array}$ & Ref. \\
\hline \multirow{5}{*}{$\begin{array}{l}\text { Peroxidase-like } \\
\text { activity }\end{array}$} & Optical & $\mathrm{Fe}_{3} \mathrm{O}_{4} @ \mathrm{ZnO}$ & $\begin{array}{l}\text { Colorimetric sensor for } \\
\text { the detection of } \mathrm{Hg} \text { (II) }\end{array}$ & $\begin{array}{l}0 \text { to } 10 \mathrm{nM} \\
\left(\mathrm{R}^{2}=0.9985\right)\end{array}$ & $23 \mathrm{nM}$ & [90] \\
\hline & Optical & $\begin{array}{c}\mathrm{Co}_{3} \mathrm{O}_{4} @ \beta \text {-cyclodextrin } \\
\text { nanoparticles }\end{array}$ & $\begin{array}{l}\text { Colorimetric sensing of } \\
\text { ascorbic acid }\end{array}$ & $10-60 \mu \mathrm{M}$ & $1.09 \mu \mathrm{M}$ & [91] \\
\hline & Optical & $\begin{array}{l}\text { Flower-like yttrium } \\
\text { vanadate }\left(\mathrm{YVO}_{4}\right) \\
\text { microstructures }\end{array}$ & Detection of $\mathrm{H}_{2} \mathrm{O}_{2}$ & $0.5 \mu \mathrm{M}-50 \mu \mathrm{M}$ & $0.126 \mu \mathrm{M}$ & [92] \\
\hline & Optical & $\begin{array}{c}\text { Cys-decorated } \mathrm{Fe}_{3} \mathrm{O}_{4} \\
\text { nanoparticle }\end{array}$ & $\begin{array}{c}\text { Colorimetric } \\
\text { nano-sensor for } \mathrm{Hg}^{2+} \\
\text { detection } \\
\text { (environmental water, } \\
\text { human urine and even } \\
\text { serum) }\end{array}$ & $0.02-90 \mathrm{nM}$ & $5.9 \mathrm{pM}$ & [93] \\
\hline & Optical & $\begin{array}{c}\text { Sodium dodecyl } \\
\text { benzene sulfonate } \\
(\mathrm{SDBS})-\mathrm{Cu}-\mathrm{CuFe} \mathrm{O}_{4}\end{array}$ & $\begin{array}{c}\text { Detection of } \mathrm{H}_{2} \mathrm{O}_{2} \text { and } \\
\text { dopamine }\end{array}$ & $\begin{array}{l}0 \text { to } 10 \mu \mathrm{M} \\
\left(\mathrm{R}^{2}=0.994\right)\end{array}$ & $0.32 \mu \mathrm{M}$ & [94] \\
\hline $\begin{array}{l}\text { Oxidase-like } \\
\text { activity }\end{array}$ & Optical & $\begin{array}{l}\text { Heparin sodium and } \\
\text { platinum nanoparticles }\end{array}$ & $\begin{array}{l}\text { Pharmaceutical analysis } \\
\text { and clinical diagnosis. } \\
\text { Colorimetric method for } \\
\text { isoniazid }\end{array}$ & $\begin{array}{c}2.5 \times 10^{-6} \text { to } \\
2.5 \times 10^{-4} \mathrm{M} \\
\left(\mathrm{R}^{2}=0.998\right)\end{array}$ & $1.7 \times 10^{-6} \mathrm{M}$ & [95] \\
\hline \multirow{2}{*}{$\begin{array}{l}\text { Oxidase-like } \\
\text { activity }\end{array}$} & Optical & $\begin{array}{l}\text { Cerium dioxide } \\
\text { nanoparticles }\end{array}$ & $\begin{array}{l}\text { Organophosphorus } \\
\text { pesticides }\end{array}$ & $\begin{array}{c}50-1000 \mathrm{ng} / \mathrm{mL} \\
\left(\mathrm{R}^{2}=0.9933\right)\end{array}$ & $7.6 \mathrm{ng} / \mathrm{mL}$ & [96] \\
\hline & Optical & $\begin{array}{c}\text { Nanolayered } \\
\text { manganese-calcium } \\
\text { oxide nanoparticles }\end{array}$ & $\begin{array}{l}\text { Detection of glucose in } \\
\text { real samples }\end{array}$ & $0.0183-0.421 \mathrm{mM}$ & $23.86 \mu \mathrm{M}$ & [97] \\
\hline \multirow{4}{*}{$\begin{array}{l}\text { Laccase like } \\
\text { activity }\end{array}$} & Optical & $\begin{array}{l}\text { Cu-tannic and acid } \\
\text { nanohybrids }\end{array}$ & $\begin{array}{l}\text { Colorimetric detection } \\
\text { of epinephrine }\end{array}$ & $\begin{array}{l}4.5 \text { to } 90 \mu \mathrm{M} \\
\left(\mathrm{R}^{2}=0.9989\right)\end{array}$ & $3.4 \mu \mathrm{M}$ & [98] \\
\hline & Optical & $\begin{array}{c}\text { Coral-like silver citrate } \\
\text { microstructures }\end{array}$ & $\begin{array}{l}\text { Catechol } \\
\text { Hydroquinone } \\
\text { 2-aminophenol } \\
\text { 2-nitrophenol } \\
\text { 1-naphthol } \\
\text { 2,6-dimethoxyphenol } \\
\text { 4-chlorophenol } \\
\text { Phenol }\end{array}$ & $\begin{array}{l}1.87-298 \mu \mathrm{M} \\
2.35-714 \mu \mathrm{M} \\
0.938-714 \mu \mathrm{M} \\
7.14-1330 \mu \mathrm{M} \\
7.14-579 \mu \mathrm{M} \\
1.33-298 \mu \mathrm{M} \\
0.623-238 \mu \mathrm{M} \\
0.623-238 \mu \mathrm{M}\end{array}$ & $\begin{array}{l}1.03 \mu \mathrm{M} \\
1.33 \mu \mathrm{M} \\
343 \mu \mathrm{M} \\
3.15 \mu \mathrm{M} \\
3.15 \mu \mathrm{M} \\
714 \mathrm{nM} \\
343 \mathrm{nM} \\
343 \mathrm{nM}\end{array}$ & [49] \\
\hline & Optical & $\begin{array}{c}\mathrm{CH}-\mathrm{Cu} \\
\text { (Combining key } \\
\text { peptides as metal } \\
\text { ligands with metal ions) }\end{array}$ & $\begin{array}{l}\text { Detection of } \\
\text { epinephrine by a } \\
\text { smartphone }\end{array}$ & & $0.31 \mu \mathrm{g} / \mathrm{mL}$ & [99] \\
\hline & $\begin{array}{l}\text { Optical and } \\
\text { electrochemical }\end{array}$ & $\mathrm{CuO}$ nanorods & $\begin{array}{l}\text { Medical diagnosis } \\
\text { Colorimetric and } \\
\text { electrochemical } \\
\text { determination of } \\
\text { epinephrine. }\end{array}$ & $0.6-18 \mu \mathrm{M}$ & $0.31 \mu \mathrm{M}$ & {$[6]$} \\
\hline
\end{tabular}


Table 6. Cont

\begin{tabular}{|c|c|c|c|c|c|c|}
\hline Nanozyme & $\begin{array}{l}\text { Transduction } \\
\text { System }\end{array}$ & Material & Application & $\begin{array}{l}\text { Detection Range } \\
\text { with a Linear } \\
\text { Correlation }\end{array}$ & $\begin{array}{l}\text { Limit of } \\
\text { Detection }\end{array}$ & Ref. \\
\hline \multirow[t]{2}{*}{$\begin{array}{l}\text { Laccase like } \\
\text { activity }\end{array}$} & Optical & $\begin{array}{l}\text { Copper ion and } \\
\text { adenosine } \\
\text { monophosphate } \\
\text { (AMP-Cu nanozymes) }\end{array}$ & $\begin{array}{l}\text { Detection and remotion } \\
\text { of phenolic compounds } \\
\text { from fruit juices }\end{array}$ & $0.1-100 \mu \mathrm{mol} \cdot \mathrm{L}^{-1}$ & $0.033 \mu \mathrm{mol} \cdot \mathrm{L}^{-1}$ & [89] \\
\hline & Optical & $\begin{array}{c}\text { Co-assembly of } \\
\text { L-cystine with } \mathrm{Cu} \text { ions }\end{array}$ & epinephrine detection & $9-455 \mu \mathrm{mol} \mathrm{L}-1$ & $2.7 \mu \mathrm{mol} \mathrm{L}{ }^{-1}$ & {$[100]$} \\
\hline $\begin{array}{l}\text { Catalase-like and } \\
\text { Peroxidase-like } \\
\text { dual enzyme } \\
\text { mimics }\end{array}$ & Optical & $\mathrm{Ag@Ag} \mathrm{WO}_{4} \mathrm{NRs}$ & $\begin{array}{l}\text { Determination of } \\
\text { glucose }\end{array}$ & $\begin{array}{c}27.7 \mu \mathrm{M} \text { to } \\
0.33 \mathrm{mM}\end{array}$ & $2.6 \mu \mathrm{M}$ & [101] \\
\hline
\end{tabular}

Since the discovery of the enzyme-like properties of nanomaterials, several nanomaterials have been employed for the synthesis of nanozymes such as metal oxides $\left(\mathrm{Fe}_{2} \mathrm{O}_{3}\right.$, $\mathrm{NiCO}_{2} \mathrm{O}_{4}$, and $\mathrm{Co}_{3} \mathrm{O}_{4}$ ), metal nanoparticles ( $\mathrm{Ag}$, $\mathrm{Au}, \mathrm{Pt}$, and $\mathrm{Pd}$ ), metal sulfides (CuS, $\mathrm{FeS}$, and $\mathrm{MoS}_{2}$ ), carbon nanomaterials polymer-coated nanoparticles and nanocomposites [25]. Some materials even have been shown to possess more than one enzyme activity. For example, molybdenum disulfide-based materials $\left(\mathrm{MoS}_{2}\right)$ have peroxidase-like activity, catalase-like activity, and superoxide dismutase activity. Additionally, $\mathrm{MoS}_{2}$ is considered a promising material due to its multiple advantages such as simple preparation, low cost, low toxicity, biodegradability, and rapid excretion [102]. Due to nanozymes not having an active site like natural enzymes, different strategies have been made to improve the catalytic properties of these nanomaterials. It has been reported that size, morphology, surface modification composition, $\mathrm{pH}$, and temperature can affect the catalytic performance of nanozymes [103]. Metal nanoparticles (NPs) have the most abundant redox sites, which are considered a great potential for detecting of analytes [104]. Nanozymes have been proved to be used as a potential chemical sensor and biosensor for the detection of glucose, phenols, $\mathrm{H}_{2} \mathrm{O}_{2}$, pesticides, bacteria, cancer cells, among others applications [105]. An official classification of nanozymes has not been established yet $[98,103]$.

\subsection{Peroxidase-like Activity}

The research on nanomaterials with peroxidase-like activity has been growing since the discovery of $\mathrm{Fe}_{3} \mathrm{O}_{4}$ nanoparticles [106,107]. Nanomaterials with peroxidase-like activity reported are metal-based nanoparticles, metal oxide-based nanomaterials, carbon-based nanomaterials (CDs), metal-organic frameworks (MOFs), hybrid nanostructures, among others. These micro and nano-materials possess excellent catalytic properties in colorimetric sensors, pollutants degradation, and disinfection [102,108-110].

$\mathrm{Fe}_{3} \mathrm{O}_{4}$ nanoparticles had an excellent peroxide-like activity, making it difficult to disperse them in an aqueous solution. To improve the stability to sense the color change, it is necessary to avoid aggregation in water samples. The most common solution is the coating of nanoparticles with compounds that contain functional groups. Christus et al. [90] designed a colorimetric sensor for $\mathrm{Hg}$ detection using $\mathrm{Fe}_{3} \mathrm{O}_{4}$ coated with $\mathrm{ZnO}$. They improve the efficiency and selectivity of nanozymes. Another advantage of $\mathrm{Fe}_{3} \mathrm{O}_{4}$ is its comparable catalytic efficiency to HRP, because of the large ferric and ferrous iron area available on their surface. However, $\mathrm{Fe}_{3} \mathrm{O}_{4}$ shows a higher $\mathrm{kM}$ for $\mathrm{H}_{2} \mathrm{O}_{2}$ than HRP. The enzyme may have additional contributions to catalysis by its natural active site as amino acid residues. The addition of amino acid residues to the structure of nanoparticles increased the affinity for the substrate. Niu et al. [93] added cysteine residues to the $\mathrm{Fe}_{3} \mathrm{O}_{4}$ nanozyme. Nevertheless, due to the interaction of Cys-Fe, the active site on $\mathrm{Fe}_{3} \mathrm{O}_{4}$ was blocked, and the nanozyme exhibited almost no peroxidase-like activity. Therefore, they used the nanoparticles to create a colorimetric $\mathrm{Hg}^{+2}$ sensor. In the presence of $\mathrm{Hg}^{+2}$, Cys could be despoiled from the $\mathrm{Cys}-\mathrm{Fe}_{3} \mathrm{O}_{4}$ particles by stronger $\mathrm{Cys}-\mathrm{Hg}^{2+}$-Cys coordination, resulting in the exposure of active $\mathrm{Fe}_{3} \mathrm{O}_{4}$ that could catalyze the oxidation of the substrate, which was the indicator of the $\mathrm{Hg}^{+2}$ presence. CDs have some advantages as biocompatibility, low toxicity, tun- 
able luminescent properties, higher water solubility, inexpensive synthesis process [107]. Bimetallic nanozymes can be an option to decrease the cost of the materials and improve their catalytic properties. Nanosheet-structured $\mathrm{Cu}-\mathrm{CuFe}_{3} \mathrm{O}_{4}$ has been reported to have higher activity than HRP; however, the affinity to TMB was weaker than HRP.

\subsection{Oxidase-like Activity}

Oxidase-like nanozymes can catalyze the oxidation of substrates to corresponding oxidized products in the presence of $\mathrm{O}_{2}$ without $\mathrm{H}_{2} \mathrm{O}_{2}$; unlike peroxidase-like nanozymes, this makes oxidase mimics appropriate for sensing assays with easy operation and high sensitivity. Recently, many inorganic nanomaterials have been found to catalyze the oxidation of substrates exhibiting oxidase-like activity such as $\mathrm{Ce}$, noble metal, $\mathrm{Mn}, \mathrm{Fe}$, $\mathrm{Cu}, \mathrm{Mb}$. The oxidase-like activity can regulate their physicochemical parameters as size, shape, composition, and surface modification [96,111]. A capping agent can be used to obtain an excellent catalytic activity of nanozyme. He et al. [95] used heparin sodium as a capping agent for obtaining heparin sodium stabilized platinum nanoparticles HS-PtNPs. The nanoparticles could catalyze the oxidation of TMB. Due to isoniazid competed with TMB to bind the active site of the HS-PtNPs, a colorimetric method was designed for isoniazid detection.

Comotti et al. [112] reported that gold nanoparticles could catalyze glucose to generate gluconic acid and $\mathrm{HO}_{2}$ in $\mathrm{O}_{2}$ presence. Hydrated glucose anion with gold surface atoms could form electron-rich species that could transform electrons from glucose to dioxygen. Detection of glucose with nanozymes with oxidase-like activity has been reported. Due to the disadvantages of glucose oxidase biosensors for glucose detection, research focuses on developing an enzyme-free glucose sensor using nanomaterials (nanowire, nanorods, nanosheets, nanoparticles and nanotubes). It has been reported the colorimetric detection of glucose by nanozymes. Rashtbari et al. [97] reported nanolayered manganese-calcium oxide nanoparticles with oxidase mimic activity. A non-enzymatic strategy for detection with the naked eye, and quantification of glucose by spectrophotometry was reported.

\subsection{Laccase-like Activity}

Most of the nanozymes reported have peroxidase, oxidase, or catalase-like activity. Laccase mimic is a new sector of nanozyme research that has been growing in recent years. Many efforts have been made to develop organic/inorganic/hybrid materials with laccase-like activity [6,98]. Laccase has a complex structure of the active site and catalytic mechanism. Due to the catalytic activity of laccase from the active site, which contains copper, copper-based nanocomposites have been fabricated to mimic laccase-like activity. Ma et al. [98] reported that $\mathrm{Cu}$-tannic acid inorganic-organic nanohybrids have excellent laccase-like activity. The reductive property of tannic acid with the reduction of $\mathrm{Cu}+2$ to $\mathrm{Cu}+$ is similar to natural laccases. The biosensor obtained for EP detection showed high tolerance to catalytic activity even when the temperature was increased to $85^{\circ} \mathrm{C}$. The detection limit was less than in previous reports, and the linear range of detection was higher 4.5 to $90 \mu \mathrm{M}$. Alizadeh et al. [6] synthesized $\mathrm{CuO}$ nanorods to mimic laccase activity and obtained a biosensor that could oxidize EP to a colored product with a LOD of $0.31 \mu \mathrm{M}$ and linear range of $0.6-18 \mu \mathrm{M}$. No interference from ascorbic acid, dopamine, and uric acid was observed. Additionally, considering that the catalytic activity of laccase comes from the bridges formed by copper and cysteine-histidine in the active site, Guan et al. [100] constructed a laccase-like catalyst through the co-assembly of L-cysteine with $\mathrm{Cu}$ ions. $\mathrm{Cu}-$ cysteine nanoleaves possess a system like laccase with superior activity during long-term incubation. The colorimetric method for EP detection had a linear range 9-455 $\mu \mathrm{M} \cdot \mathrm{L}^{-1}$ and a lower limit of detection $2.7 \mu \mathrm{M} \cdot \mathrm{L}^{-1}$. This study shows that the addition of cysteine with copper is more similar than only using copper, thus, better results have been obtained.

Cooper-containing complexes have been synthesized with different organic ligands and carbon dots (CDs) [113]. Ligands such as porphyrins, phthalocyanine, and imidazole have been used to mimic laccases. Additionally, nucleotides are highly versatile ligands, 
and nucleotide-coordinated $\mathrm{Cu}+2$ complexes have laccase-like activity. The coordination of polymers such as Magnetic $\mathrm{Cu} /$ nucleotides has shown excellent laccase-like activity [113]. Liang et al. [114] used nucleotides as ligands and obtained a guanosine monophosphate coordinated copper with tremendous laccase-like activity. CDs have been used as skeletons with active copper as an active center. These nanozymes showed better stability and different optimal $\mathrm{pH}$ than natural laccases. Equally, they could detect hydroquinone by the oxidation of p-phenylenediamine to produce a color reaction and were used as fluorescent [115].

\section{Nanozymes-Enzymes Pool}

Enzymatic catalysis is still vulnerable by the poor stability of enzymes. Consequently, studies have focused on the integration of different functional natural or artificial enzyme catalysts. In these systems, enzyme catalysis processes can be promoted by highly stable nanomaterials [116]. As it was mentioned in the previous section, different nanomaterials have been shown enzymatic-like properties. However, even when nanozymes represent a vast potential research potential, some nanozymes still need natural enzymes to detect some molecules as glucose, ethanol, among others (Table 7). Cascade reactions with enzymes are performed for the quantification of the analytes. Helping from the combination of enzymes and nanozymes, the stability of the enzyme can be enhanced and the activity of cascade reactions. Nevertheless, the performance of these systems is affected specialty for their interactions and their kinetic coincidence. Consequently, rational engineering of the multienzyme system architecture is the key to effective cascade reactions and high stability between the two systems [117]. In Figure 6, advantages and disadvantages of nanozymes and nanozymes-enzymes pool are shown.

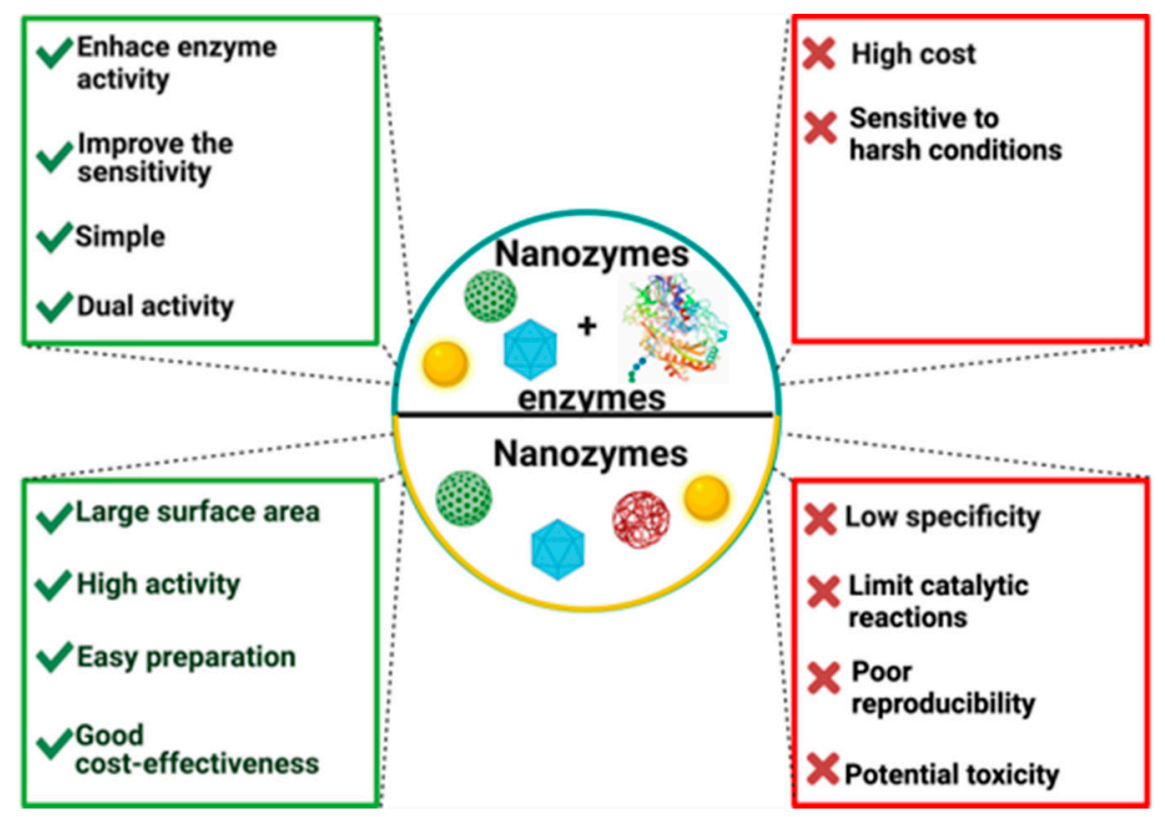

Figure 6. Advantages and disadvantages of nanozymes and nanozymes-enzymes pool.

Detection of organophosphate pesticides is an example of cascade reaction with the intrinsic peroxidase-like activity of graphene oxide to produce a color reaction in the presence of acetylcholinesterase (AChE) and choline oxidase (CHO) [118]. Similarly, since the quantification of $\mathrm{H}_{2} \mathrm{O}_{2}$ can connect glucose oxidation and TMB oxidation, the nanozymes can be used for the colorimetric detection of glucose, using a chemo-enzymatic cascade system. Tran et al. [119] developed a colorimetric detection of glucose by the combining graphene oxide sheets with silver nanoparticles (AgNPs@rGO) with GOx. GOx catalyzes the glucose oxidation to $\mathrm{O}_{2}$, leading to gluconic acid and $\mathrm{H}_{2} \mathrm{O}_{2}$, and $\mathrm{H}_{2} \mathrm{O}_{2}$ can be detected as a product by the nanozyme. Guo et al. [120] synthesized a nanocomposite of 
cobalt oxide $(\mathrm{CoO})$ with a peroxidase-like activity, assembled onto ordered-mesoporous carbon (CoO-OMC). The nanomaterial shows a good activity upon the oxidation of TMB by $\mathrm{H}_{2} \mathrm{O}_{2}$ to produce a color change, and when GOx was coupled, it was possible to develop a glucose sensor. Smutok et al. [121] developed a sensor for the detection of ethanol and glucose. They synthesized a micro/nanocomposite with peroxidase-like activity based on carbon microfibers modified by hemin and gold nanoparticles coupled with alcohol oxidase and glucose oxidase. They used enzymes to enhance the potential of their biosensor. Parl et al. [108] reported developing a sensor for the colorimetric and fluorometric detection of glucose using a composite metal with platinum and ruthenium $(\mathrm{Pt}-\mathrm{Ru})$ by cascade reaction with the glucose oxidase.

Nanozymes are also considered a platform for enzyme immobilization due to nanozymes coupled with natural enzymes that can eliminate the diffusion limitation for substrates and enhance enzymatic activity. Recently, metal-organic frameworks (MOFs) have gained considered attention due to their high potential as a universal platform for the immobilization of enzymes and nanozymes. High flexibility and tunability permit the encapsulation of catalysts with diverse sizes and functions for effective cascade reaction [116].

Table 7. Nanozyme-enzyme pool in biosensors.

\begin{tabular}{|c|c|c|c|c|c|c|c|}
\hline $\begin{array}{c}\text { Enzyme-like } \\
\text { Activity }\end{array}$ & Nanozyme & Enzyme & $\begin{array}{c}\text { Transduction } \\
\text { System }\end{array}$ & Application & Range & $\begin{array}{c}\text { Limit of } \\
\text { Detection }\end{array}$ & Ref. \\
\hline \multirow{5}{*}{$\begin{array}{l}\text { Peroxidase- } \\
\text { like } \\
\text { activity }\end{array}$} & \multirow{2}{*}{$\begin{array}{l}\text { Carbon microfibers } \\
\text { modified by hemin } \\
\text { and gold } \\
\text { nanoparticles }\end{array}$} & \multirow{2}{*}{$\begin{array}{l}\text { Alcohol } \\
\text { oxidase and } \\
\text { glucose } \\
\text { oxidase }\end{array}$} & \multirow[t]{2}{*}{ Electrochemical } & $\begin{array}{l}\text { Detection of } \\
\text { ethanol }\end{array}$ & $0.01-0.15 \mathrm{mM}$ & $0.005 \mathrm{mM}$ & \multirow{2}{*}[121]{} \\
\hline & & & & $\begin{array}{l}\text { Detection of } \\
\text { glucose }\end{array}$ & $0.1-0.9 \mathrm{mM}$ & $0.05 \mathrm{mM}$ & \\
\hline & Ceria nanomaterials & \multirow{2}{*}{$\begin{array}{l}\text { Glucose } \\
\text { oxidase }\end{array}$} & \multirow{2}{*}{ Optical } & $\begin{array}{c}\text { Detection of } \\
\mathrm{H}_{2} \mathrm{O}_{2}\end{array}$ & $10 \mu \mathrm{M}-50 \mathrm{mM}$ & $2 \mu \mathrm{M}$ & \multirow{2}{*}[122]{} \\
\hline & $\begin{array}{c}\mathrm{Mn}(\mathrm{II}) / \mathrm{CeO} 2 \\
\text { nanorods } \\
\text { nanocomposites }\end{array}$ & & & $\begin{array}{l}\text { Detection of } \\
\text { glucose }\end{array}$ & $10 \mu \mathrm{M}-100 \mathrm{mM}$ & $8.6 \mu \mathrm{M}$ & \\
\hline & $\begin{array}{l}\text { Silver nanoparticles } \\
\text { decorated on reduced } \\
\text { graphene oxide } \\
\text { sheets (AgNPs@rGO) } \\
\text { nanocomposite }\end{array}$ & $\begin{array}{l}\text { Glucose } \\
\text { oxidase }\end{array}$ & Optical & $\begin{array}{l}\text { Colorimetric } \\
\text { glucose } \\
\text { biosensor } \\
\text { colorimetric } \\
\text { glucose } \\
\text { biosensor }\end{array}$ & $125 \mu \mathrm{M}$ to $1 \mathrm{mM}$ & $40 \mu \mathrm{M}$ & [119] \\
\hline & Graphene oxide & $\begin{array}{c}\text { Acetylcholineste } \\
\text { and choline } \\
\text { oxidase }\end{array}$ & ape Optical & $\begin{array}{l}\text { Colorimetric } \\
\text { detection of } \\
\text { organophos- } \\
\text { phourus } \\
\text { pesticides }\end{array}$ & $1-200 \mathrm{ng} / \mathrm{mL}$ & $2 \mathrm{ppb}$ & [118] \\
\hline \multirow{5}{*}{$\begin{array}{l}\text { Peroxidase- } \\
\text { like } \\
\text { activity }\end{array}$} & $\begin{array}{c}\text { Cobalt oxide } \\
\text { supported ordered } \\
\text { mesoporous carbon } \\
\text { (CoO-OMC) }\end{array}$ & $\begin{array}{l}\text { Glucose } \\
\text { oxidase }\end{array}$ & Optical & $\begin{array}{l}\text { Colorimetric } \\
\text { detection of } \\
\text { glucose }\end{array}$ & $0.1-5.0 \mathrm{mM}$ & $68 \mu \mathrm{M}$ & {$[120]$} \\
\hline & \multirow[t]{2}{*}{$\begin{array}{c}\text { Bimetallic PtRu } \\
\text { nanoparticles (nPtRu) }\end{array}$} & \multirow{2}{*}{$\begin{array}{l}\text { Alcohol } \\
\text { oxidase and } \\
\text { methylamine } \\
\text { oxidase }\end{array}$} & \multirow{2}{*}{ Electrochemical } & $\begin{array}{c}\text { Food analysis } \\
\text { ethanol } \\
\text { detection }\end{array}$ & 25-200 $\mu \mathrm{M}$ & $3 \mu \mathrm{M}$ & \multirow[t]{2}{*}[123]{} \\
\hline & & & & $\begin{array}{l}\text { Methylamine } \\
\text { detection }\end{array}$ & $20-600 \mu \mathrm{M}$ & $2.5 \mu \mathrm{M}$ & \\
\hline & $\begin{array}{c}\text { Metallic cobalt } \\
\text { nanoparticles } \\
\text { encapsulated in } \\
\text { metal-organic } \\
\text { frameworks derived } \\
\text { carbon }\end{array}$ & $\begin{array}{l}\text { Glucose } \\
\text { oxidase }\end{array}$ & Optical & $\begin{array}{l}\text { Colorimetric } \\
\text { detection of } \\
\text { glucose }\end{array}$ & 0.25 to $30 \mu \mathrm{M}$ & $156 \mathrm{nM}$ & [104] \\
\hline & Prussian Blue & Lactate oxidase & Electrochemical & $\begin{array}{l}\text { Detection of } \\
\text { lactate }\end{array}$ & & & {$[124]$} \\
\hline \multirow[b]{2}{*}{$\begin{array}{l}\text { Peroxidase- } \\
\text { like } \\
\text { activity }\end{array}$} & $\begin{array}{l}\text { Au nanoparti- } \\
\text { cle/polyluminol }\end{array}$ & $\begin{array}{l}\text { Glucose } \\
\text { oxidase }\end{array}$ & Optical & $\begin{array}{l}\text { Detection of } \\
\text { glucose }\end{array}$ & $10-1000 \mu \mathrm{M}$ & $10 \mu \mathrm{M}$ & {$[125]$} \\
\hline & Pt-Ru nanozymes & $\begin{array}{l}\text { Glucose } \\
\text { oxidase }\end{array}$ & Optical & $\begin{array}{l}\text { Colorimetric } \\
\text { and } \\
\text { fluorometric } \\
\text { glucose } \\
\text { detection }\end{array}$ & $0.25-3.0 \mathrm{mM}$ & 0.988 and $138 \mu \mathrm{M}$ & [108] \\
\hline
\end{tabular}




\section{Conclusions and Future Perspectives}

This review tried to collect some recent trends in enzyme-based biosensors and nanozyme-based biosensors; however, only a small part of the known nanozymes and enzymes used in biosensors is presented in this review. Enzyme-based biosensors and nanozyme-based biosensors have ultrasensitive detection limits and multiple health, food, and environmental applications. In enzyme-based biosensors, horseradish peroxidase, glucose oxidase, and laccase are some of the main reported enzymes. Even when these systems are already commercial products in different applications fields, there is a need to keep improving these technologies. The main challenging issue in the enzyme-based biosensor is the immobilization process due to their stability, shelf life, and reusability related to the efficiency of the immobilization between the platform and the enzyme. Bi-enzyme biosensors represent an excellent alternative for the detection of one or more analytes. The selection of enzymes is an important factor in the development of the biosensor because they must have similar operating conditions (temperature, $\mathrm{pH}$, concentration).

Using cost-effective nanozymes is a promising way for biosensor development. Nanozyme is progressing faster, that it is difficult to describe all the advances in one review. However, even with all the advantages of using nanozymes, multiple limitations in their application need to be solved, such as the lack of substrate specificity, the fouling of the nanozyme surface due to the absorption of some compounds, and the limited types of enzymes that they can mimic. Therefore, it is required to keep researching the natural active site of enzymes to mimic and enhance the specificity. Additionally, the combination or the synergetic mechanism reported with enzymes and nanozymes represent a promising alternative to face this problem because their interaction could enhance the selectivity and sensitivity of these systems. Future work should focus on understanding the mechanism of interaction between the nanomaterials and enzymes, and on the fabrication of new materials with more enzyme-like activities that could be applied in clinical diagnosis, food analysis and environmental monitoring.

Author Contributions: Funding acquisition, R.P.-S. and H.M.N.I.; investigation, L.A.-R., M.R.-A., J.R.-R., J.E.S.-H. and E.M.M.-M.; project administration, J.E.S.-H. and M.R.-A.; supervision, J.R.-R., M.R.-A. and R.P.-S.; writing—original draft, L.A.-R. and M.R.-A.; writing-review and editing, M.R.A., H.M.N.I. and R.P.-S. All authors have read and agreed to the published version of the manuscript.

Funding: This research was supported by Consejo Nacional de Ciencia y Tecnología (CONACYT) Doctoral Fellowship No. 486638 awarded to author Lynette Alvarado Ramírez.

Acknowledgments: The PhD scholarship awarded by Consejo Nacional de Ciencia y Tecnología (CONACYT), Mexico to Lynette Alvarado Ramírez (486638) is gratefully acknowledged. We are also thankful to "Programa Iberoamericano de Ciencia y Tecnología para el Desarrollo" in the Latin American development network "Lacasas Inmovilizadas para 1 Degradación de Compuestos Aromáticos en Aguas Residuales" (LIDA, project 318RT0552). All listed authors are also grateful to their representative universities for providing literature access. Figures 1 and 3-6 were created with BioRender.com.

Conflicts of Interest: The authors declare no conflict of interest. The funders had no role in the design of the study; in the collection, analyses, or interpretation of data; in the writing of the manuscript, or in the decision to publish the results.

\section{References}

1. Ali, J.; Najeeb, J.; Ali, M.A.; Aslam, M.F.; Raza, A. Biosensors: Their Fundamentals, Designs, Types and Most Recent Impactful Applications: A Review. J. Biosens. Bioelectron. 2017, 8, 1-9. [CrossRef]

2. Meshram, B.; Agrawal, A.; Adil, S.; Ranvir, S.; Sande, K. Biosensor and its Application in Food and Dairy Industry: A Review. Int. J. Curr. Microbiol. Appl. Sci. 2018, 7, 3305-3324. [CrossRef]

3. Bhalinge, P.; Kumar, S.; Jadhav, A.; Suman, S.; Gujjar, P.; Perla, N. Biosensors: Nanotools of Detection-A Review. Int. J. Healthc. Biomed. Res. 2016, 04, 26-39.

4. Bocanegra-Rodríguez, S.; Jornet-Martínez, N.; Molins-Legua, C.; Campíns-Falcó, P. New Reusable Solid Biosensor with Covalent Immobilization of the Horseradish Peroxidase Enzyme: In Situ Liberation Studies of Hydrogen Peroxide by Portable Chemiluminescent Determination. ACS Omega 2020, 5, 2419-2427. [CrossRef] 
5. Kaya, H.O.; Cetin, A.E.; Azimzadeh, M.; Topkaya, S.N. Pathogen detection with electrochemical biosensors: Advantages, challenges and future perspectives. J. Electroanal. Chem. 2021, 882, 114989. [CrossRef]

6. Alizadeh, N.; Ghasemi, S.; Salimi, A.; Sham, T.-K.; Hallaj, R. CuO nanorods as a laccase mimicking enzyme for highly sensitive colorimetric and electrochemical dual biosensor: Application in living cell epinephrine analysis. Colloids Surf. B Biointerfaces 2020, 195, 111228. [CrossRef]

7. Azad, T.; Singaravelu, R.; Brown, E.E.; Taha, Z.; Rezaei, R.; Arulanandam, R.; Boulton, S.; Diallo, J.-S.; Ilkow, C.S.; Bell, J.C. SARS-CoV-2 S1 NanoBiT: A nanoluciferase complementation-based biosensor to rapidly probe SARS-CoV-2 receptor recognition. Biosens. Bioelectron. 2021, 180, 113122. [CrossRef]

8. Koushki, E.; Mirzaei Mohammadabadi, F.; Baedi, J.; Ghasedi, A. The effects of glucose and glucose oxidase on the Uv-vis spectrum of gold nanoparticles: A study on optical biosensor for saliva glucose monitoring. Photodiagn. Photodyn. Ther. 2020, $30,101771$. [CrossRef]

9. Liu, Y.; Nan, X.; Shi, W.; Liu, X.; He, Z.; Sun, Y.; Ge, D. A glucose biosensor based on the immobilization of glucose oxidase and Au nanocomposites with polynorepinephrine. RSC Adv. 2019, 9, 16439-16446. [CrossRef]

10. De Oliveira Wardak, C.; Paczosa-Bator, B.; Malinowski, S. Application of cold plasma corona discharge in preparation of laccase-based biosensors for dopamine determination. Mater. Sci. Eng. C 2020, 116, 111199. [CrossRef]

11. Neto, J.O.; Rezende, S.G.; Lobón, G.S.; Garcia, T.A.; Macêdo, I.; Garcia, L.F.; Alves, V.F.; Torres, I.M.S.; Santiago, M.; Schimidt, F.; et al. Electroanalysis and laccase-based biosensor on the determination of phenolic content and antioxidant power of honey samples. Food Chem. 2017, 237, 1118-1123. [CrossRef]

12. Piroozmand, F.; Mohammadipanah, F.; Faridbod, F. Emerging biosensors in detection of natural products. Synth. Syst. Biotechnol. 2020, 5, 293-303. [CrossRef]

13. Rodríguez-Delgado, M.M.; Alemán-Nava, G.S.; Rodriguez-Delgado, J.M.; Dieck-Assad, G.; Martinez-Chapa, S.O.; Barceló, D.; Parra, R. Laccase-based biosensors for detection of phenolic compounds. TrAC Trends Anal. Chem. 2015, 74, 21-45. [CrossRef]

14. Othman, A.M.; Wollenberger, U. Amperometric biosensor based on coupling aminated laccase to functionalized carbon nanotubes for phenolics detection. Int. J. Biol. Macromol. 2020, 153, 855-864. [CrossRef]

15. Zhao, K.; Veksha, A.; Ge, L.; Lisak, G. Near real-time analysis of para-cresol in wastewater with a laccase-carbon nanotube-based biosensor. Chemosphere 2020, 269, 128699. [CrossRef]

16. Temoçin, Z. Designing of a stable and selective glucose biosensor by glucose oxidase immobilization on glassy carbon electrode sensitive to $\mathrm{H} 2 \mathrm{O} 2$ via nanofiber interface. J. Appl. Electrochem. 2021, 51, 283-293. [CrossRef]

17. Stasyuk, N.; Smutok, O.; Demkiv, O.; Prokopiv, T.; Gayda, G.; Nisnevitch, M.; Gonchar, M. Synthesis, Catalytic Properties and Application in Biosensorics of Nanozymes and Electronanocatalysts: A Review. Sensors 2020, 20, 4509. [CrossRef]

18. Perumal, V.; Hashim, U. Advances in biosensors: Principle, architecture and applications. J. Appl. Biomed. 2014, 12, 1-15. [CrossRef]

19. Nagraik, R.; Sharma, A.; Kumar, D.; Mukherjee, S.; Sen, F.; Kumar, A.P. Amalgamation of biosensors and nanotechnology in disease diagnosis: Mini-review. Sens. Int. 2021, 2, 100089. [CrossRef]

20. AlHamoud, Y.; Yang, D.; Kenston, S.S.F.; Liu, G.; Liu, L.; Zhou, H.; Ahmed, F.; Zhao, J. Advances in biosensors for the detection of ochratoxin A: Bio-receptors, nanomaterials, and their applications. Biosens. Bioelectron. 2019, 141, 111418. [CrossRef]

21. Nguyen, H.H.; Lee, S.H.; Lee, U.J.; Fermin, C.D.; Kim, M. Immobilized Enzymes in Biosensor Applications. Materials 2019, 12, 121. [CrossRef] [PubMed]

22. Clark, L.C.; Lyons, C. Electrode Systems for Continuous Monitoring in Cardiovascular Surgery. Ann. N. Y. Acad. Sci. 1962, 102, 29-45. [CrossRef]

23. Wang, T.; Fan, X.; Li, R.; Xu, J.; Liu, J. Multi-Enzyme-Synergetic ultrathin protein nanosheets display high efficient and switch on/off antibacterial activities. Chem. Eng. J. 2021, 416, 129082. [CrossRef]

24. De Jesús Rostro-Alanis, M.; Mancera-Andrade, E.I.; Patiño, M.B.G.; Arrieta-Baez, D.; Cardenas, B.; Martinez-Chapa, S.O.; Saldívar, R.P. Nanobiocatalysis: Nanostructured materials-A minireview. Biocatalysis 2016, 2, 1-24. [CrossRef]

25. Ahangari, H.; Kurbanoglu, S.; Ehsani, A.; Uslu, B. Latest trends for biogenic amines detection in foods: Enzymatic biosensors and nanozymes applications. Trends Food Sci. Technol. 2021, 112, 75-87. [CrossRef]

26. Pérez, J.A.C.; Sosa-Hernández, J.E.; Hussain, S.M.; Bilal, M.; Parra, R.; Iqbal, H.M. Bioinspired biomaterials and enzyme-based biosensors for point-of-care applications with reference to cancer and bio-imaging. Biocatal. Agric. Biotechnol. 2019, 17, 168-176. [CrossRef]

27. Gul, I.; Ahmad, M.S.; Naqvi, S.M.S.; Hussain, A.; Wali, R.; Farooqi, A.A.; Ahmed, I. Polyphenol oxidase (PPO) based biosensors for detection of phenolic compounds: A Review. J. Appl. Biol. Biotechnol. 2017, 5, 72-85. [CrossRef]

28. Gonzalez-Coronel, L.A.; Cobas, M.; Rostro-Alanis, M.D.J.; Parra-Saldívar, R.; Hernandez-Luna, C.E.; Pazos, M.; Sanromán, M. Immobilization of laccase of Pycnoporus sanguineus CS43. New Biotechnol. 2017, 39, 141-149. [CrossRef]

29. Alvarado-Ramírez, L.; Rostro-Alanis, M.; Rodríguez-Rodríguez, J.; Castillo-Zacarías, C.; Sosa-Hernández, J.E.; Barceló, D.; Iqbal, H.M.; Parra-Saldívar, R. Exploring current tendencies in techniques and materials for immobilization of laccases-A review. Int. J. Biol. Macromol. 2021, 181, 683-696. [CrossRef]

30. Feizabadi, M.; Soleymanpour, A.; Faridnouri, H.; Ajloo, D. Improving stability of biosensor based on covalent immobilization of horseradish peroxidase by $\gamma$-aminobutyric acid and application in detection of H2O2. Int. J. Biol. Macromol. 2019, 136, 597-606. [CrossRef] 
31. Cock, L.S.; Arenas, A.M.Z.; Aponte, A.A. Use of Enzymatic Biosensors as Quality Indices: A Synopsis of Present and Future Trends in The Food Industry. Chil. J. Agric. Res. 2009, 69, 270-280. [CrossRef]

32. Bilal, M.; Rasheed, T.; Zhao, Y.; Iqbal, H.M. Agarose-chitosan hydrogel-immobilized horseradish peroxidase with sustainable bio-catalytic and dye degradation properties. Int. J. Biol. Macromol. 2019, 124, 742-749. [CrossRef] [PubMed]

33. Vineh, M.B.; Saboury, A.A.; Poostchi, A.A.; Rashidi, A.; Parivar, K. Stability and activity improvement of horseradish peroxidase by covalent immobilization on functionalized reduced graphene oxide and biodegradation of high phenol concentration. Int. J. Biol. Macromol. 2018, 106, 1314-1322. [CrossRef] [PubMed]

34. De Oliveira, F.K.; Santos, L.O.; Buffon, J.G. Mechanism of action, sources, and application of peroxidases. Food Res. Int. 2021, 143, 110266. [CrossRef]

35. Ahammad, A.J.S. Hydrogen Peroxide Biosensors Based on Horseradish Peroxidase and Hemoglobin. J. Biosens. Bioelectron. 2012, S9, 001. [CrossRef]

36. Da Silva Freires, A.; Botelho, C.N.; Silva, S.M.; Goulart, M.O.F.; Damos, F.S.; Luz, R.D.C.S. Photoelectrochemical biosensor for 1,4-dihydroxybenzene based on copper sulfide and horseradish peroxidase enzyme: Application in skin cream samples. Microchem. J. 2020, 159, 105487. [CrossRef]

37. Zeng, R.; Wang, J.; Wang, Q.; Tang, D.; Lin, Y. Horseradish peroxidase-encapsulated DNA nanoflowers: An innovative signalgeneration tag for colorimetric biosensor. Talanta 2021, 221, 121600. [CrossRef]

38. Marzo, A.M.L.; Mayorga-Martinez, C.C.; Pumera, M. 3D-printed graphene direct electron transfer enzyme biosensors. Biosens. Bioelectron. 2020, 151, 111980. [CrossRef]

39. Shin, J.-H.; Lee, M.-J.; Choi, J.-H.; Song, J.-A.; Kim, T.-H.; Oh, B.-K. Electrochemical H2O2 biosensor based on horseradish peroxidase encapsulated protein nanoparticles with reduced graphene oxide-modified gold electrode. Nano Converg. 2020, 7, 39. [CrossRef]

40. Spychalska, K.; Zajac, D.; Cabaj, J. Electrochemical biosensor for detection of $17 \beta$-estradiol using semi-conducting polymer and horseradish peroxidase. RSC Adv. 2020, 10, 9079-9087. [CrossRef]

41. Narayanan, J.S.; Slaughter, G. AuNPs-HRP microneedle biosensor for ultrasensitive detection of hydrogen peroxide for organ preservation. Med. Devices Sens. 2018, 1, e10015. [CrossRef]

42. Mohammad, R.; Ahmad, M.; Heng, L.Y. Amperometric capsaicin biosensor based on covalent immobilization of horseradish peroxidase (HRP) on acrylic microspheres for chilli hotness determination. Sens. Actuators B Chem. 2017, 241, 174-181. [CrossRef]

43. Lee, I.; Probst, D.; Klonoff, D.; Sode, K. Continuous glucose monitoring systems-Current status and future perspectives of the flagship technologies in biosensor research. Biosens. Bioelectron. 2021, 181, 113054. [CrossRef]

44. Bagyalakshmi, S.; Sivakami, A.; Balamurugan, K. A Zno nanorods based enzymatic glucose biosensor by immobilization of glucose oxidase on a chitosan film. Obes. Med. 2020, 18, 100229. [CrossRef]

45. Newman, J.D.; Turner, A. Home blood glucose biosensors: A commercial perspective. Biosens. Bioelectron. 2005, 20, 2435-2453. [CrossRef]

46. Jayakumar, K.; Bennett, R.; Leech, D. Electrochemical glucose biosensor based on an osmium redox polymer and glucose oxidase grafted to carbon nanotubes: A design-of-experiments optimisation of current density and stability. Electrochim. Acta 2021, 371, 137845. [CrossRef]

47. Jiménez-Fiérrez, F.; González-Sánchez, M.I.; Jiménez-Pérez, R.; Iniesta, J.; Valero, E. Glucose Biosensor Based on Disposable Activated Carbon Electrodes Modified with Platinum Nanoparticles Electrodeposited on Poly(Azure A). Sensors 2020, $20,4489$. [CrossRef]

48. Barrios-Estrada, C.; de Jesús Rostro-Alanis, M.; Muñoz-Gutiérrez, B.D.; Iqbal, H.M.; Kannan, S.; Parra-Saldívar, R. Emergent contaminants: Endocrine disruptors and their laccase-assisted degradation-A review. Sci. Total Environ. 2018, 612, 1516-1531. [CrossRef]

49. Koyappayil, A.; Kim, H.T.; Lee, M.-H. 'Laccase-like' properties of coral-like silver citrate micro-structures for the degradation and determination of phenolic pollutants and adrenaline. J. Hazard. Mater. 2021, 412, 125211. [CrossRef]

50. Zhou, W.; Zhang, W.; Cai, Y. Laccase immobilization for water purification: A comprehensive review. Chem. Eng. J. 2020, 403, 126272. [CrossRef]

51. Orlikowska, M.; Rostro-Alanis, M.D.J.; Bujacz, A.; Hernández-Luna, C.; Rubio, R.; Parra, R.; Bujacz, G. Structural studies of two thermostable laccases from the white-rot fungus Pycnoporus sanguineus. Int. J. Biol. Macromol. 2018, 107, 1629-1640. [CrossRef]

52. Bilal, M.; Jing, Z.; Zhao, Y.; Iqbal, H.M. Immobilization of fungal laccase on glutaraldehyde cross-linked chitosan beads and its bio-catalytic potential to degrade bisphenol A. Biocatal. Agric. Biotechnol. 2019, 19, 101174. [CrossRef]

53. Jarosz-Wilkolazka, A.; Ruzgas, T.; Gorton, L. Amperometric detection of mono- and diphenols at Cerrena unicolor laccasemodified graphite electrode: Correlation between sensitivity and substrate structure. Talanta 2005, 66, 1219-1224. [CrossRef]

54. Coelho, J.H.; Eisele, A.; Valezi, C.F.; Mattos, G.; Schirmann, J.G.; Dekker, R.F.; Barbosa-Dekker, A.M.; Sartori, E.R. Exploring the exocellular fungal biopolymer botryosphaeran for laccase-biosensor architecture and application to determine dopamine and spironolactone. Talanta 2019, 204, 475-483. [CrossRef]

55. Sangubotla, R.; Kim, J. Fiber-optic biosensor based on the laccase immobilization on silica-functionalized fluorescent carbon dots for the detection of dopamine and multi-color imaging applications in neuroblastoma cells. Mater. Sci. Eng. C 2021, $122,111916$. [CrossRef] 
56. Zhang, M.; Zhang, Y.; Yang, C.; Ma, C.; Tang, J. A smartphone-assisted portable biosensor using laccase-mineral hybrid microflowers for colorimetric determination of epinephrine. Talanta 2021, 224, 121840. [CrossRef]

57. Li, Z.; Zheng, Y.; Gao, T.; Liu, Z.; Zhang, J.; Zhou, G. Fabrication of biosensor based on core-shell and large void structured magnetic mesoporous microspheres immobilized with laccase for dopamine detection. J. Mater. Sci. 2018, 53, 7996-8008. [CrossRef]

58. Rubio-Govea, R.; Hickey, D.P.; García-Morales, R.; Rodriguez-Delgado, M.; Domínguez-Rovira, M.A.; Minteer, S.D.; OrnelasSoto, N.; García-García, A. MoS2 nanostructured materials for electrode modification in the development of a laccase based amperometric biosensor for non-invasive dopamine detection. Microchem. J. 2020, 155, 104792. [CrossRef]

59. Cevher, C.; Bekmezci, S.A.; Soylemez, S.; Udum, Y.A.; Toppare, L.; Çırpan, A. Indenoquinoxalinone based conjugated polymer substrate for laccase biosensor. Mater. Chem. Phys. 2021, 257, 123788. [CrossRef]

60. Bounegru, A.; Apetrei, C. Laccase and Tyrosinase Biosensors Used in the Determination of Hydroxycinnamic Acids. Int. J. Mol. Sci. 2021, 22, 4811. [CrossRef]

61. García-Guzmán, J.J.; López-Iglesias, D.; Cubillana-Aguilera, L.; Lete, C.; Lupu, S.; Palacios-Santander, J.M.; Bellido-Milla, D. Assessment of the Polyphenol Indices and Antioxidant Capacity for Beers and Wines Using a Tyrosinase-Based Biosensor Prepared by Sinusoidal Current Method. Sensors 2019, 19, 66. [CrossRef] [PubMed]

62. Wu, L.; Lu, X.; Niu, K.; Dhanjai; Chen, J. Tyrosinase nanocapsule based nano-biosensor for ultrasensitive and rapid detection of bisphenol A with excellent stability in different application scenarios. Biosens. Bioelectron. 2020, 165, 112407. [CrossRef] [PubMed]

63. Shaban, S.M.; Moon, B.-S.; Pyun, D.-G.; Kim, D.-H. A colorimetric alkaline phosphatase biosensor based on p-aminophenolmediated growth of silver nanoparticles. Colloids Surf. B Biointerfaces 2021, 205, 111835. [CrossRef] [PubMed]

64. e Silva, T.S.; Soares, I.P.; Lacerda, L.R.G.; Cordeiro, T.A.R.; Ferreira, L.; Franco, D.L. Electrochemical modification of electrodes with polymers derived from of hydroxybenzoic acid isomers: Optimized platforms for an alkaline phosphatase biosensor for pesticide detection. Mater. Chem. Phys. 2020, 252, 123221. [CrossRef]

65. Kim, J.Y.; Sung, G.Y.; Park, M. Efficient Portable Urea Biosensor Based on Urease Immobilized Membrane for Monitoring of Physiological Fluids. Biomedicines 2020, 8, 596. [CrossRef]

66. Wang, Z.; Ma, B.; Shen, C.; Cheong, L.-Z. Direct, selective and ultrasensitive electrochemical biosensing of methyl parathion in vegetables using Burkholderia cepacia lipase@MOF nanofibers-based biosensor. Talanta 2019, 197, 356-362. [CrossRef]

67. Hasanah, U.; Sani, N.D.M.; Heng, L.Y.; Idroes, R.; Safitri, E. Construction of a Hydrogel Pectin-Based Triglyceride Optical Biosensor with Immobilized Lipase Enzymes. Biosensors 2019, 9, 135. [CrossRef]

68. Mercante, L.; Iwaki, L.; Scagion, V.; Oliveira, O.; Mattoso, L.; Correa, D. Electrochemical Detection of Bisphenol A by Tyrosinase Immobilized on Electrospun Nanofibers Decorated with Gold Nanoparticles. Electrochem 2021, 2, 41-49. [CrossRef]

69. Nedellec, Y.; Gondran, C.; Gorgy, K.; Mc Murtry, S.; Agostini, P.; Elmazria, O.; Cosnier, S. Microcapsule-based biosensor containing catechol for the reagent-free inhibitive detection of benzoic acid by tyrosinase. Biosens. Bioelectron. 2021, 180, 113137. [CrossRef]

70. Mirzaei, F.; Mirzaei, M.; Torkzadeh-Mahani, M. A hydrophobin-based-biosensor layered by an immobilized lactate dehydrogenase enzyme for electrochemical determination of pyruvate. Bioelectrochemistry 2019, 130, 107323. [CrossRef]

71. Liu, L.; Chen, C.; Chen, C.; Kang, X.; Zhang, H.; Tao, Y.; Xie, Q.; Yao, S. Poly(noradrenalin) based bi-enzyme biosensor for ultrasensitive multi-analyte determination. Talanta 2019, 194, 343-349. [CrossRef]

72. Arana-Peña, S.; Carballares, D.; Morellon-Sterlling, R.; Berenguer-Murcia, Á.; Alcántara, A.R.; Rodrigues, R.C.; FernandezLafuente, R. Enzyme co-immobilization: Always the biocatalyst designers' choice ... or not? Biotechnol. Adv. 2020, $51,107584$. [CrossRef]

73. Xu, K.; Chen, X.; Zheng, R.; Zheng, Y. Immobilization of Multi-Enzymes on Support Materials for Efficient Biocatalysis. Front. Bioeng. Biotechnol. 2020, 8, 660. [CrossRef]

74. Yokus, M.A.; Songkakul, T.; Pozdin, V.A.; Bozkurt, A.; Daniele, M.A. Wearable multiplexed biosensor system toward continuous monitoring of metabolites. Biosens. Bioelectron. 2020, 153, 112038. [CrossRef]

75. Ibadullaeva, S.Z.; Appazov, N.; Tarahovsky, Y.S.; Zamyatina, E.A.; Fomkina, M.G.; Kim, Y.A. Amperometric Multi-Enzyme Biosensors: Development and Application, A Short Review. Biophysics 2019, 64, 696-707. [CrossRef]

76. Xu, S.; Qi, H.; Zhou, S.; Zhang, X.; Zhang, C. Mediatorless amperometric bienzyme glucose biosensor based on horseradish peroxidase and glucose oxidase cross-linked to multiwall carbon nanotubes. Microchim. Acta 2014, 181, 535-541. [CrossRef]

77. Yang, H.; Gong, C.; Miao, L.; Xu, F. A Glucose Biosensor based on Horseradish Peroxidase and Glucose Oxidase Co-entrapped in Carbon Nanotubes Modified Electrode. Int. J. Electrochem. Sci. 2017, 12, 4958-4969. [CrossRef]

78. Hernández-Ibáñez, N.; García-Cruz, L.; Montiel, V.; Foster, C.; Banks, C.; Iniesta, J. Electrochemical lactate biosensor based upon chitosan/carbon nanotubes modified screen-printed graphite electrodes for the determination of lactate in embryonic cell cultures. Biosens. Bioelectron. 2016, 77, 1168-1174. [CrossRef]

79. Montereali, M.; Della Seta, L.; Vastarella, W.; Pilloton, R. A disposable Laccase-Tyrosinase based biosensor for amperometric detection of phenolic compounds in must and wine. J. Mol. Catal. B Enzym. 2010, 64, 189-194. [CrossRef]

80. Fang, Y.; Umasankar, Y.; Ramasamy, R.P. A novel bi-enzyme electrochemical biosensor for selective and sensitive determination of methyl salicylate. Biosens. Bioelectron. 2016, 81, 39-45. [CrossRef]

81. Moreno-Guzmán, M.; García-Carmona, L.; Molinero-Fernández, Á.; Cava, F.; Gil, M.L.; Escarpa, A. Bi-enzymatic biosensor for on-site, fast and reliable electrochemical detection of relevant D-amino acids in bacterial samples. Sens. Actuators B Chem. 2017, 242, 95-101. [CrossRef] 
82. Shoja, Y.; Rafati, A.A.; Ghodsi, J. Polythiophene supported MnO2 nanoparticles as nano-stabilizer for simultaneously electrostatically immobilization of d-amino acid oxidase and hemoglobin as efficient bio-nanocomposite in fabrication of dopamine bi-enzyme biosensor. Mater. Sci. Eng. C 2017, 76, 637-645. [CrossRef]

83. Rahman, M.; Li, X.-B.; Kim, J.; Lim, B.O.; Ahammad, A.S.; Lee, J.-J. A cholesterol biosensor based on a bi-enzyme immobilized on conducting poly(thionine) film. Sens. Actuators B Chem. 2014, 202, 536-542. [CrossRef]

84. Liu, Y.; Lv, B.; Liu, A.; Liang, G.; Yin, L.; Pu, Y.; Wei, W.; Gou, S.; Liu, S. Multicolor sensor for organophosphorus pesticides determination based on the bi-enzyme catalytic etching of gold nanorods. Sens. Actuators B Chem. 2018, 265, 675-681. [CrossRef]

85. Molinnus, D.; Beging, S.; Lowis, C.; Schöning, M.J. Towards a Multi-Enzyme Capacitive Field-Effect Biosensor by Comparative Study of Drop-Coating and Nano-Spotting Technique. Sensors 2020, 20, 4924. [CrossRef] [PubMed]

86. Castillo, N.E.T.; Melchor-Martínez, E.M.; Sierra, J.S.O.; Ramírez-Torres, N.M.; Sosa-Hernández, J.E.; Iqbal, H.M.; Parra-Saldívar, R. Enzyme mimics in-focus: Redefining the catalytic attributes of artificial enzymes for renewable energy production. Int. J. Biol. Macromol. 2021, 179, 80-89. [CrossRef]

87. Wong, E.L.S.; Vuong, K.Q.; Chow, E. Nanozymes for Environmental Pollutant Monitoring and Remediation. Sensors 2021, $21,408$. [CrossRef]

88. Zhang, X.; Lin, S.; Liu, S.; Tan, X.; Dai, Y.; Xia, F. Advances in organometallic/organic nanozymes and their applications. Coord. Chem. Rev. 2021, 429, 213652. [CrossRef]

89. Huang, H.; Lei, L.; Bai, J.; Zhang, L.; Song, D.; Zhao, J.; Li, J.; Li, Y. Efficient elimination and detection of phenolic compounds in juice using laccase mimicking nanozymes. Chin. J. Chem. Eng. 2021, 29, 167-175. [CrossRef]

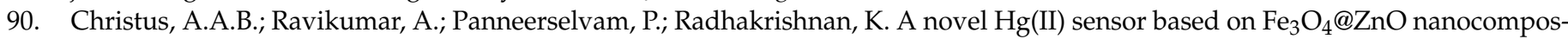
ite as peroxidase mimics. Appl. Surf. Sci. 2018, 449, 669-676. [CrossRef]

91. Lu, W.; Zhang, J.; Li, N.; You, Z.; Feng, Z.; Natarajan, V.; Chen, J.; Zhan, J. Co3O4@ $\beta$-cyclodextrin with synergistic peroxidasemimicking performance as a signal magnification approach for colorimetric determination of ascorbic acid. Sens. Actuators $B$ Chem. 2020, 303, 127106. [CrossRef]

92. Hou, P.; Ju, P.; Hao, L.; Chen, C.; Jiang, F.; Ding, H.; Sun, C. Colorimetric determination of hydrogen peroxide based on the robust peroxidase-like activities of flower-like YVO4 microstructures. Colloids Surfaces A: Physicochem. Eng. Asp. 2021, 618, 126427. [CrossRef]

93. Niu, X.; He, Y.; Li, X.; Zhao, H.; Pan, J.; Qiu, F.; Lan, M. A peroxidase-mimicking nanosensor with Hg2+-triggered enzymatic activity of cysteine-decorated ferromagnetic particles for ultrasensitive $\mathrm{Hg} 2+$ detection in environmental and biological fluids. Sens. Actuators B Chem. 2019, 281, 445-452. [CrossRef]

94. Xia, F.; Shi, Q.; Nan, Z. Improvement of peroxidase-like activity and application for detection of $\mathrm{H} 2 \mathrm{O} 2$ and dopamine for SDBS-Cu-CuFe2O4. Surf. Interfaces 2021, 24, 101109. [CrossRef]

95. He, S.-B.; Yang, L.; Lin, X.-L.; Chen, L.-M.; Peng, H.-P.; Deng, H.-H.; Xia, X.-H.; Chen, W. Heparin-platinum nanozymes with enhanced oxidase-like activity for the colorimetric sensing of isoniazid. Talanta 2020, 211, 120707. [CrossRef]

96. Chen, Z.; Wang, Y.; Mo, Y.; Long, X.; Zhao, H.; Su, L.; Duan, Z.; Xiong, Y. ZIF-8 directed templating synthesis of CeO2 nanoparticles and its oxidase-like activity for colorimetric detection. Sens. Actuators B Chem. 2020, 323, 128625. [CrossRef]

97. Rashtbari, S.; Dehghan, G.; Amini, M. An ultrasensitive label-free colorimetric biosensor for the detection of glucose based on glucose oxidase-like activity of nanolayered manganese-calcium oxide. Anal. Chim. Acta 2020, 1110, 98-108. [CrossRef]

98. Ma, H.; Zheng, N.; Chen, Y.; Jiang, L. Laccase-like catalytic activity of Cu-tannic acid nanohybrids and their application for epinephrine detection. Colloids Surfaces A: Physicochem. Eng. Asp. 2021, 613, 126105. [CrossRef]

99. Wang, J.; Huang, R.; Qi, W.; Su, R.; Binks, B.P.; He, Z. Construction of a bioinspired laccase-mimicking nanozyme for the degradation and detection of phenolic pollutants. Appl. Catal. B Environ. 2019, 254, 452-462. [CrossRef]

100. Guan, M.; Wang, M.; Qi, W.; Su, R.; He, Z. Biomineralization-inspired copper-cystine nanoleaves capable of laccase-like catalysis for the colorimetric detection of epinephrine. Front. Chem. Sci. Eng. 2020, 15, 310-318. [CrossRef]

101. Koyappayil, A.; Berchmans, S.; Leec, M.H. Dual enzyme-like properties of silver nanoparticles decorated Ag2WO4 nanorods and its application for $\mathrm{H}_{2} \mathrm{O}_{2}$ and glucose sensing. Colloids Surf. B Biointerfaces 2020, 189, 110840. [CrossRef]

102. Xu, J.; Cai, R.; Zhang, Y.; Mu, X. Molybdenum disulfide-based materials with enzyme-like characteristics for biological applications. Colloids Surf. B Biointerfaces 2021, 200, 111575. [CrossRef]

103. Huang, Y.; Ren, J.; Qu, X. Nanozymes: Classification, Catalytic Mechanisms, Activity Regulation, and Applications. Chem. Rev. 2019, 119, 4357-4412. [CrossRef]

104. Dong, W.; Zhuang, Y.; Li, S.; Zhang, X.; Chai, H.; Huang, Y. High peroxidase-like activity of metallic cobalt nanoparticles encapsulated in metal-organic frameworks derived carbon for biosensing. Sens. Actuators B Chem. 2018, 255, $2050-2057$. [CrossRef]

105. Ye, M.-L.; Zhu, Y.; Lu, Y.; Gan, L.; Zhang, Y.; Zhao, Y.-G. Magnetic nanomaterials with unique nanozymes-like characteristics for colorimetric sensors: A review. Talanta 2021, 230, 122299. [CrossRef]

106. Gao, L.; Zhuang, J.; Nie, L.; Zhang, J.; Zhang, Y.; Gu, N.; Wang, T.; Feng, J.; Yang, D.; Perrett, S.; et al. Intrinsic peroxidase-like activity of ferromagnetic nanoparticles. Nat. Nanotechnol. 2007, 2, 577-583. [CrossRef]

107. Das, S.; Ngashangva, L.; Mog, H.; Gogoi, S.; Goswami, P. An insight into the mechanism of peroxidase-like activity of carbon dots. Opt. Mater. 2021, 115, 111017. [CrossRef] 
108. Park, Y.; Gupta, P.K.; Tran, V.-K.; Son, S.E.; Hur, W.; Lee, H.B.; Park, J.Y.; Kim, S.N.; Seong, G.H. PVP-stabilized PtRu nanozymes with peroxidase-like activity and its application for colorimetric and fluorometric glucose detection. Colloids Surf. B Biointerfaces 2021, 204, 111783. [CrossRef]

109. Bilal, M.; Hussain, N.; Américo-Pinheiro, J.H.P.; Almulaiky, Y.Q.; Iqbal, H.M. Multi-enzyme co-immobilized nano-assemblies: Bringing enzymes together for expanding bio-catalysis scope to meet biotechnological challenges. Int. J. Biol. Macromol. 2021, 186, 735-749. [CrossRef]

110. González-González, R.B.; Sharma, A.; Parra-Saldívar, R.; Ramirez-Mendoza, R.A.; Bilal, M.; Iqbal, H.M. Decontamination of emerging pharmaceutical pollutants using carbon-dots as robust materials. J. Hazard. Mater. 2021, 423, 423127145. [CrossRef]

111. Chong, Y.; Liu, Q.; Ge, C. Advances in oxidase-mimicking nanozymes: Classification, activity regulation and biomedical applications. Nano Today 2021, 37, 101076. [CrossRef]

112. Comotti, M.; Della Pina, C.; Falletta, E.; Rossi, M. Aerobic Oxidation of Glucose with Gold Catalyst: Hydrogen Peroxide as Intermediate and Reagent. Adv. Synth. Catal. 2006, 348, 313-316. [CrossRef]

113. Zhang, S.; Lin, F.; Yuan, Q.; Liu, J.; Li, Y.; Liang, H. Robust magnetic laccase-mimicking nanozyme for oxidizing ophenylenediamine and removing phenolic pollutants. J. Environ. Sci. 2020, 88, 103-111. [CrossRef] [PubMed]

114. Liang, H.; Lin, F.; Zhang, Z.; Liu, B.; Jiang, S.; Yuan, Q.; Liu, J. Multicopper Laccase Mimicking Nanozymes with Nucleotides as Ligands. ACS Appl. Mater. Interfaces 2017, 9, 1352-1360. [CrossRef] [PubMed]

115. Ren, X.; Liu, J.; Ren, J.; Tang, F.; Meng, X. One-pot synthesis of active copper-containing carbon dots with laccase-like activities. Nanoscale 2015, 7, 19641-19646. [CrossRef]

116. Cheng, X.; Zhou, J.; Chen, J.; Xie, Z.; Kuang, Q.; Zheng, L. One-step synthesis of thermally stable artificial multienzyme cascade system for efficient enzymatic electrochemical detection. Nano Res. 2019, 12, 3031-3036. [CrossRef]

117. Losada-Garcia, N.; Cabrera, Z.; Urrutia, P.; Garcia-Sanz, C.; Andreu, A.; Palomo, J. Recent Advances in Enzymatic and Chemoenzymatic Cascade Processes. Catalysts 2020, 10, 1258. [CrossRef]

118. Chu, S.; Huang, W.; Shen, F.; Li, T.; Li, S.; Xu, W.; Lv, C.; Luo, Q.; Liu, J. Graphene oxide-based colorimetric detection of organophosphorus pesticides via a multi-enzyme cascade reaction. Nanoscale 2020, 12, 5829-5833. [CrossRef]

119. Tran, H.V.; Nguyen, N.D.; Tran, C.T.; Tran, L.T.; Le, T.D.; Tran, H.T.; Piro, B.; Huynh, C.D.; Nguyen, T.N.; Nguyen, N.T.; et al. Silver nanoparticles-decorated reduced graphene oxide: A novel peroxidase-like activity nanomaterial for development of a colorimetric glucose biosensor. Arab. J. Chem. 2020, 13, 6084-6091. [CrossRef]

120. Guo, Y.; Yan, L.; Zhang, R.; Ren, H.; Liu, A. CoO-supported ordered mesoporous carbon nanocomposite based nanozyme with peroxidase-like activity for colorimetric detection of glucose. Process. Biochem. 2019, 81, 92-98. [CrossRef]

121. Smutok, O.; Kavetskyy, T.; Prokopiv, T.; Serkiz, R.; Wojnarowska-Nowak, R.; Šauša, O.; Novák, I.; Berek, D.; Melman, A.; Gonchar, M. New micro/nanocomposite with peroxidase-like activity in construction of oxidases-based amperometric biosensors for ethanol and glucose analysis. Anal. Chim. Acta 2021, 1143, 201-209. [CrossRef] [PubMed]

122. Yue, Y.; Wei, H.; Guo, J.; Yang, Y. Ceria-based peroxidase-mimicking nanozyme with enhanced activity: A coordination chemistry strategy. Colloids Surfaces A: Physicochem. Eng. Asp. 2020, 610, 125715. [CrossRef]

123. Stasyuk, N.; Gayda, G.; Zakalskiy, A.; Zakalska, O.; Serkiz, R.; Gonchar, M. Amperometric biosensors based on oxidases and PtRu nanoparticles as artificial peroxidase. Food Chem. 2019, 285, 213-220. [CrossRef]

124. Vokhmyanina, D.V.; Andreeva, K.D.; Komkova, M.A.; Karyakina, E.E.; Karyakin, A.A. 'Artificial peroxidase' nanozyme-Enzyme based lactate biosensor. Talanta 2020, 208, 120393. [CrossRef]

125. Lou, F.; Xie, X.; Li, Q.; Wang, Y.; Li, Q. One-pot synthesis of Au nanoparticle/polyluminol/glucose oxidase bifunctional nanospheres for solid-state electrochemiluminescent sensor. J. Electroanal. Chem. 2021, 888, 115166. [CrossRef] 